\title{
The ACCENT-VOCBAS field campaign on biosphere-atmosphere interactions in a Mediterranean ecosystem of Castelporziano (Rome): site characteristics, climatic and meteorological conditions, and eco-physiology of vegetation
}

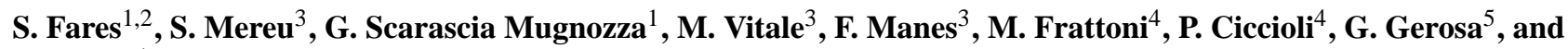 \\ F. Loreto ${ }^{1}$ \\ ${ }^{1}$ CNR (National Research Council) - Istituto di Biologia Agroambientale e Forestale, Via Salaria km 29, 300, \\ 00016 Monterotondo Scalo, Rome, Italy \\ ${ }^{2}$ Department of Environmental Science, Policy, and Management, University of California, 137 Mulford Hall, Berkeley, \\ CA 94720, USA \\ ${ }^{3}$ Department of Plant Biology, University of Rome "La Sapienza", Piazzale Aldo Moro 5, 00185 Rome, Italy \\ ${ }^{4}$ CNR (National Research Council) - Istituto di Metodologie Chimiche, Via Salaria km. 29, 300, 00016 Monterotondo Scalo, \\ Rome, Italy \\ ${ }^{5}$ Università cattolica del sacro cuore, Via Musei 41, 25-121 Brescia, Italy
}

Received: 17 November 2008 - Published in Biogeosciences Discuss.: 22 January 2009

Revised: 27 May 2009 - Accepted: 3 June 2009 - Published: 18 June 2009

\begin{abstract}
Biosphere-atmosphere interactions were investigated on a sandy dune Mediterranean ecosystem in a field campaign held in 2007 within the frame of the European Projects ACCENT and VOCBAS. The campaign was carried out in the Presidential estate of Castelporziano, a periurban park close to Rome. Former campaigns (e.g. BEMA) performed in Castelporziano investigated the emission of biogenic volatile organic compounds (BVOC). These campaigns focused on pseudosteppe and evergreen oak groves whereas the contribution of the largely biodiverse dune vegetation, a prominent component of the Mediterranean ecosystem, was overlooked. While specific aspects of the campaign will be discussed in companion papers, the general climatic and physiological aspects are presented here, together with information regarding BVOC emission from the most common plant species of the dune ecosystem. During the campaign regular air movements were observed, dominated by moderate nocturnal land breeze and diurnal sea breeze. A regular daily increase of ozone concentration in the air was also observed, but daily peaks of ozone were lower than those measured in summer on the same site. The site was ideal
\end{abstract}

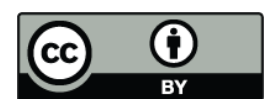

Correspondence to: F. Loreto (francesco.loreto@ibaf.cnr.it) as a natural photochemical reactor to observe reaction, transport and deposition processes occurring in the Mediterranean basin, since the sea-land breeze circulation allowed a strong mixing between biogenic and anthropogenic emissions and secondary pollutants. Measurements were run in May, when plant physiological conditions were optimal, in absence of severe drought and heat stress. Foliar rates of photosynthesis and transpiration were as high as generally recorded in unstressed Mediterranean sclerophyllous plants. Most of the plant species emitted high level of monoterpenes, despite measurements being made in a period in which emissions of volatile isoprenoids could be restrained by developmental and environmental factors, such as leaf age and relatively low air temperature. Emission of isoprene was generally low. Accounting for the high monoterpene spring emission of the dune ecosystem may be important to correct algorithms at regional and ecosystem levels, and to interpret measurements of fluxes of volatile isoprenoids and secondary pollutants.

\section{Introduction}

The Mediterranean ecosystems represent $1 \%$ of the Earth's land surface, and are concentrated mainly in the Mediterranean basin, with coastal ecosystems playing consequently

Published by Copernicus Publications on behalf of the European Geosciences Union. 
an important role. Coastal sand dunes are natural structures which protect the coast by absorbing energy from wind, tide and wave action, and host ecosystems made by pioneering species which are adapted to life at the interface between see and land. The typical dune vegetation communities are part of the larger "macchia" or "maquis" ecosystem, which in its degraded state is referred to as "garrigue". In Italy, the macchia covers $2-3 \%$ of the territory (INFC, 2003) and is made primarily of evergreen shrubs. This vegetation stabilizes coastal sand dunes, and shelters inland vegetation from sea winds and consequent damages due to marine aerosol. Despite the large biodiversity characterizing the macchia vegetation, all plant species show ecological adaptations to the Mediterranean environmental conditions, which are characterized by hot and dry summers, mild and often rainy winters, recurrent exposure to salinity due to sea breeze and saline ground water table, and sandy soil with poor organic fraction and nutrients.

Plants establishing on coastal sand dunes are subjected to several environmental fluctuations which affect their growth, survival and community structure (Maun, 1994). Typically, the morphological and structural adaptations to drought, salinity and high temperatures that are observed in Mediterranean plants include small plant size, globular shape of the canopy, and sclerophytic leaves with thick cuticles and dense mesophyll (Thompson, 2005). To endure recurrent episodes of heat stress, drought, and salt stress, plants living in the dunes carry out two alternative ecological strategies. A few plants have a "water spending strategy" with stomata responding strongly to water availability and allowing excellent $\mathrm{CO}_{2}$ diffusion inside leaves and high rates of photosynthesis when water is available. Most plant species present a "water saving strategy", with stomatal opening permanently restricted by anatomical, morphological and physiological traits, and low rates of carbon assimilation even in the absence of environmental constraints. These plants show a more efficient water use under harsh conditions (Thompson, 2005).

Another line of defence against biotic and abiotic stresses is constituted by the synthesis and release of trace gases often referred to as biogenic volatile organic compounds (BVOC). The emission of isoprenoids and oxygenated volatiles is common in plants and is particularly widespread among the plant species of Mediterranean ecosystems, although reports about emissions from plants of the dune ecosystems are scarce. Isoprenoids are believed to strengthen membranes by protecting leaves against damage caused by heat and oxidative stresses (Vickers et al., 2009). Oxygenated compounds are indicators of damage occurring at cellular membranes and are released during membrane or cell wall degradation. Methanol and C-6 compounds are especially emitted at high rates under these conditions (Loreto et al., 2006).

Many of these trace gases are very reactive, and, once emitted in a polluted atmosphere that is enriched by anthropogenic emission of $\mathrm{NO}_{\mathrm{x}}$, may fuel production of ozone
(Chameides et al., 1988), secondary organic aerosols and particles (Claeys et al., 2004; Verheggen et al., 2007). These ancillary and unexpected effects of BVOC captured the attention of a multidisciplinary community of scientists that hopes to better understand the possible contribution of biogenic substances to pollution events. The impact of BVOC is expected to be more evident where biogenic and anthropogenic compounds are likely to react, for instance in urban areas, industrial parks and peri-urban green-belts and rural areas. When the sea breeze circulation is activated over the coast, the plants of the dune ecosystem are located at the entrance of the photochemical reactor regulating the ozone production downind. When the breeze switches into a land system at night, emitted BVOC can react with primary and secondary pollutants. Some of them, such as monoterpenes or sesquitepenes emitted with a temperature-dependent mechanism, can act as a night time sink of ozone leading to carbonyl and radical formation (Ciccioli and Mannozzi, 2007). Because of the complexity of factors influencing the behaviour of sandy dune plants and their critical location, coastal ecosystems of the Mediterranean region deserve specific studies, in which emission and deposition of photochemical oxidants and their precursors need to be determined, together with those of primary production and exchange of energy and matter with the atmosphere, namely water, $\mathrm{CO}_{2}$ and heat. In particular, fluxes of BVOC have been measured so far in coastal ecosystems (such as pseudosteppe and evergreen oak stands) which are different from the dune ecosystem both for the speciesspecific composition and for the environmental conditions (Ciccioli et al., 1997, 2003).

The Presidential Estate of Castelporziano is a large park at the southeastern edge of the large conurbation of Rome. Since 1951, Castelporziano has been an intact and preserved natural laboratory, where climate, ecological, geological and atmospheric researches are carried out by International research groups. Because of the large biodiversity preserved, the typical Mediterranean climate, and the proximity with urban pollution sources, the park has been a favoured site for the study of the interactions between biosphere and atmosphere. A large campaign was held in Castelporziano more than ten years ago within the framework of the European "Biogenic Emissions in the Mediterranean Area" (BEMA, 1997) project, to identify BVOC emitting plants and to estimate fluxes of isoprenoid emission in the atmosphere that could influence the chemistry of the troposphere (BEMA, 1997). Ten years later, two projects: the European Union Network of Excellence on Atmospheric Chemistry (ACCENT) and the European Science Foundation programme on Volatile Organic Compounds in the Biosphere-Atmosphere Interactions (VOCBAS), jointly organized a field campaign on the Castelporziano site. There were several reasons to expand BVOC measurements in Castelporziano. Since the pioneering BEMA campaign, outstanding progresses have been made in the inventory and understanding of BVOC emissions by plants. For instance, the advent of the Proton Transfer 
Reaction-Mass Spectrometry has allowed measurements of fluxes of trace gases with unprecedented speed and sensitivity (Lindinger et al., 1998), which makes flux measurements possible with eddy covariance techniques (Rinne et al., 2001; Davison et al., 2009). Moreover, scientific progresses have demonstrated that the emission of volatile isoprenoids is not only controlled by light and temperature (Guenther et al., 1995) but also change with leaf development (Fuentes and Wang, 1999), and in response to environmental constraints, especially salinity (Loreto and Delfine, 2000) and drought (Brilli et al., 2007). It is clear now that emission factors vary on different ecosystems, which makes essential knowledge of species-specific emission factors to correctly implement emission models, especially since the high resolution of the latest models at regional scale (Guenther et al., 2006) imposes a more refined assessment of emissions. Finally, the BEMA campaign characterized species composition and emission patterns of a retro-dunal macchia ecosystem (Owen et al., 1997; Ciccioli et al., 1997), during summer, that is, in a period in which vegetation already underwent strong physiological limitations due to drought. The ACCENT-VOCBAS campaign concentrated on the coastal dune, on a vegetation rich with BVOC-emitting species (Owen et al., 1997), and was performed on May-June 2007, when environmental constraints are still mild and fast vegetative growth typically occurs in the Mediterranean areas (Mooney and Dunn, 1970).

In summary, the field campaign in Castelporziano addressed the following main scientific objectives, as specifically reported in the referenced papers:

a) to assess with a new generation of instruments the species-specific BVOC emission by dune vegetation (this paper; Davison et al., 2009);

b) to determine, with joint field measurements, BVOC emission rates and physiological conditions from plants that were at the beginning of their growing season, and that were presumably yet unaffected by environmental stressors that strongly limit carbon fixation and allocation to secondary metabolites over dry and hot Mediterranean summers (this paper; Mereu et al., 2009);

c) to measure by disjunct eddy covariance (Karl et al., 2002) fluxes of BVOC at the ecosystem level on an ecosystem that has been never investigated previously (Davison et al., 2009);

d) to integrate concurrent leaf measurements of BVOC, $\mathrm{CO}_{2}$ and $\mathrm{H}_{2} \mathrm{O}$ fluxes driven by physiological processes with ecosystem measurements, supplying information for models of BVOC emissions and reactivity on the macchia vegetation (this paper; Vitale et al., 2009);

e) to assess, simultaneously to BVOC measurements and over the same area, the presence of air pollutants, focusing on ozone, $\mathrm{NO}_{\mathrm{x}}$, and particles, in order to estimate whether the possibility exists for BVOC to react with anthropogenic compounds (Atkinson and Arey, 2003), initiating on site the complex chain of reactions that may lead to the formation of secondary pollutants, or protecting plants from pollution dam- age, as recently reported (Loreto and Fares, 2007) (Gerosa et al., 2009);

f) to assess, through concurrent measurements of meteorological and climatological parameters, whether the climatic factors may affect BVOC emissions and may explain air mass movements, and the consequent possibility that pollutants be formed or transported on peri-urban and rural areas (this paper; Davison et al., 2009).

\section{Material and methods}

\subsection{Site information}

The experimental site is located in the Presidential Estate of Castelporziano, $41^{\circ} 41^{\prime} 54.56^{\prime \prime} \mathrm{N}, 12^{\circ} 21^{\prime} 9.50^{\prime \prime} \mathrm{E}$, It covers and area of about 6000 ha located $25 \mathrm{~km} \mathrm{SW}$ from the center of Rome, Italy. The Mediterranean ecosystems are well represented and preserved inside the Presidential Estate, which contains more than 1000 plant species. The part of the Estate facing the Tyrrhenian sea was chosen for the 2007 field campaign (Fig. 1). This area is characterized by sand dunes, 4-7 $\mathrm{m}$ high a.s.l., with mixed garrigue-type and maquis-type vegetation especially in the humid retro-dune area (Bernetti, 1997; Pignatti et al., 2001). The specific location of the experimental site was $100 \mathrm{~m}$ from the coast line, between a first and a second dune layer. An area of $1070 \mathrm{~m}^{2}$ was used for the study on vegetation characteristics as described below.

According to phytoclimatic studies (Blasi, 1993), the experimental area belongs to a Thermo-Mediterranaean region, with long and prolonged stress aridity during summer periods, and a moderate cold stress during winter. The soil of the experimental site is a typical Regosol with a sandy texture and low water-holding capacity, which exacerbates early drought. This soil is not evolved, with an "A" horizon increasing in thickness with the distance from the sea. The chemical properties of the soil are dominated by the strong presence of carbonate elements $\left(0.8 \%\right.$ of $\left.\mathrm{CaCO}_{3}\right)$ that create an alkaline $\mathrm{pH}$ of 8.3 (Francaviglia et al., 2006). Organic matter is heterogeneously present in the first horizon of the soil which is also rich in fine roots, reflecting the patched presence of vegetation described in Table 1 . The total content of soil organic carbon is in the range of $3.1 \mathrm{~g}(\mathrm{C}) \mathrm{kg}^{-1}$ soil, with high rates of microbial activity which also favoured a high mineralization rate (Trinchera et al., 1998; Pinzari et al., 1999). The retro-dune areas, very close to the experimental site, contain small water-pools, in which water temporarily accumulates, especially during winter, as a function of water-table level and rainfall rate.

\subsection{Measurement of environmental parameters}

Meteorological data were collected during the years 20052007 at two stations located inside the Castelporziano estate. The Tor Paterno station was located $6 \mathrm{~km}$ to the south of the experimental site, but at a similar distance from the coast. 
Table 1. Physiognomic measurements of plant features and estimation of the plant cover of the dune ecosystem at Castelporziano experimental site, Rome, central Italy. $\mathrm{H}_{\text {max }}$ and $\mathrm{H}_{\text {mean }}$ (standard deviation in parenthesis related to all individuals in the study area) indicate the maximal and the mean height of plants, respectively. LAI is the Leaf Area Index. In parenthesis the standard deviations for $\mathrm{H}_{m e a n}$ and LAI (standard deviation in parenthesys related to all individuals in the study area) are shown. Leaf biomass, and the area covered by each species, in the two different ecosystems ("Garigue" and "Maquis"), is reported as a percentage and as total. Missing data are not available.

\begin{tabular}{|c|c|c|c|c|c|c|c|c|c|c|c|c|}
\hline \multirow{3}{*}{$\begin{array}{l}\text { species } \\
\text { Arbutus unedo }\end{array}$} & \multirow{3}{*}{$\begin{array}{c}\mathrm{H}_{\max } \\
(\mathrm{cm}) \\
230\end{array}$} & \multirow{2}{*}{\multicolumn{2}{|c|}{$\begin{array}{c}\mathrm{H}_{\text {mean }} \\
(\mathrm{cm})\end{array}$}} & \multirow{2}{*}{\multicolumn{2}{|c|}{$\begin{array}{c}\text { LAI } \\
\left(\mathrm{m}^{2} \mathrm{~m}^{-2}\right)\end{array}$}} & \multirow{3}{*}{$\begin{array}{c}\text { Leaf biom. } \\
\left(\mathrm{kg} \mathrm{m}^{-2}\right) \\
0.17\end{array}$} & \multicolumn{2}{|c|}{ Total cover } & \multicolumn{2}{|c|}{ "Garigue" cover } & \multicolumn{2}{|c|}{ "Maquis" cover } \\
\hline & & & & & & & $\left(\mathrm{m}^{2}\right)$ & $(\%)$ & $\left(\mathrm{m}^{2}\right)$ & $(\%)$ & $\left(\mathrm{m}^{2}\right)$ & $(\%)$ \\
\hline & & 137 & $(55.2)$ & 2.9 & $(0.31)$ & & 224.2 & 21.9 & 55.5 & 5.4 & 168.7 & 16.5 \\
\hline Rosmarinum officinalis & 150 & 77 & $(28.6)$ & 2.5 & $(0.38)$ & 0.13 & 175.7 & 17.2 & 175.7 & 17.2 & & \\
\hline Quercus ilex & 300 & 187 & $(60.2)$ & 2.9 & $(0.27)$ & 0.20 & 149.1 & 14.6 & 12.1 & 1.2 & 137.0 & 13.4 \\
\hline Phillyrea latifolia & 220 & 116 & $(45.4)$ & 1.3 & $(0.21)$ & 0.23 & 144.2 & 14.1 & 41.0 & 4.0 & 103.2 & 10.1 \\
\hline Erica multiflora & 160 & 93 & (27.3) & 1.9 & $(0.17)$ & 0.18 & 126.7 & 12.4 & 121.9 & 11.9 & 4.8 & 0.5 \\
\hline Cistus spp. & 150 & 68 & (28.6) & 0.6 & $(0.23)$ & 0.16 & 46.9 & 4.6 & 46.9 & 4.6 & & \\
\hline Erica arborea & 220 & 212 & $(10.0)$ & 4.5 & $(1.12)$ & 0.19 & 15.7 & 1.5 & & & 15.7 & 1.5 \\
\hline Pistacia lentiscus & 143 & 90 & (35.6) & 2.2 & $(0.41)$ & 0.29 & 12.2 & 1.2 & 12.2 & 1.2 & & \\
\hline Smilax aspera & 150 & 80 & $(49.7)$ & 2.4 & $(0.63)$ & 0.11 & 10.7 & 1.0 & 10.7 & 1.0 & & \\
\hline Daphne gnidium & 150 & 98 & $(30.0)$ & 0.9 & $(0.30)$ & 0.09 & 5.6 & 0.5 & 5.6 & 0.5 & & \\
\hline Helicrisum litoreum & 40 & 26 & n.d. & 1.5 & $(0.11)$ & 0.16 & 4.3 & 0.4 & 4.3 & 0.4 & & \\
\hline Juneperus phoenicea & 170 & 120 & n.d. & 3.1 & $(0.21)$ & 0.27 & 5.4 & 0.5 & 0.9 & 0.1 & 4.6 & 0.4 \\
\hline Juniperus oxycedrus & 40 & 32 & $(13.7)$ & 3.1 & $(0.34)$ & 0.27 & 0.9 & 0.1 & 0.9 & 0.1 & & \\
\hline Mean & 163 & 103 & $(37.0)$ & 2.3 & $(0.27)$ & & & & & & & \\
\hline
\end{tabular}

The Carboeurope station (serving the Carboeurope-IP European project, and managed by the University of Tuscia) was located at $500 \mathrm{~m} \mathrm{NE}$ from the sandy dune site. In Tor Paterno, hourly values of temperature were recorded with a MP100A sensor (Rototronic, Huntington, NY, USA). A sonic anemometer (W200P, Vector instruments, Rhyl, UK) was used to instantaneously measure wind speed and directions, and a pluviometer (ARG 100, Environmental measurements, Sunderland, UK) was used to measure daily precipitation. All instruments were connected to a data logger (CR23X, Campbell scientifics, Shepshed, UK). Collected data were downloaded monthly and stored in the data-base of the Estate. The Carboeurope station was equipped with similar sensors, but meteorological data were complemented with sensors for the determination of atmospheric pressure and the flux of water and $\mathrm{CO}_{2}$, by Eddy Covariance.

The Bagnouls-Gaussen's diagrams were used to report the monthly averages of air temperatures and precipitation. The intersection (grey area) of the precipitation curve with the average temperatures indicates a period of aridity (Bagnouls and Gaussen, 1957).

Minimum and maximum monthly temperatures and precipitation were used to generate the Mitrakos' diagram, which identifies the Monthly Cold Stress (MCS) and the Monthly Drought Stress (MDS) indices, expressed in stress units and calculated according to the intensity and duration of cold and drought stress periods, as described by Mitrakos (1980). In brief, the MCS index was calculated according to Eq. (1):

$\mathrm{MCS}=8^{*}(10-T)$ where $T$ is the average of the monthly minimal temperatures. For $T=10^{\circ} \mathrm{C}, \mathrm{MCS}=0$ (considering $10^{\circ} \mathrm{C}$ as a threshold for the vegetative activity for Mediterranean plants); for $T=-2.5^{\circ} \mathrm{C}, \mathrm{MCS}$ is assumed to be 100 (assuming that minimal values of 2.5 correspond to the maximal cold stress).

The MDS index was calculated according the hypothesis that when monthly precipitation is below $50 \mathrm{~mm}$ drought stress occurs (Eq. 2):

$\operatorname{MDS}=2^{*}(50-P)$

where $P$ is the sum of the monthly precipitation $(\mathrm{mm})$. For $P=0, \mathrm{MDS}=100$; for $P=50, \mathrm{MDS}=0$.

Continuous monitoring of ozone was performed during the campaign from above canopy using a scaffold $(6 \mathrm{~m})$ built in the middle of our experimental area. Air was sampled at a rate of $3 \mathrm{~L} \mathrm{~min}^{-1}$ with a vacuum pump through teflon tubing and passed into a photometric $\mathrm{O}_{3}$ analyzer (1008 Dasibi Environmental Corp., Glendale, CA, USA) mounted into a cabin $10 \mathrm{~m}$ distant from the scaffold. Ozone concentrations in Castelporziano were compared to those recorded at the EMEP station of Montelibretti located downwind the city of Rome, along the main direction followed by air masses in high pressure summer conditions (sea-land breeze circulation regime) (Ciccioli et al., 1999).

\subsection{Measurement of vegetation composition and distri- bution}

An inventory of vascular species composition and their distribution in the $1070 \mathrm{~m}^{2}$-wide experimental area around the 


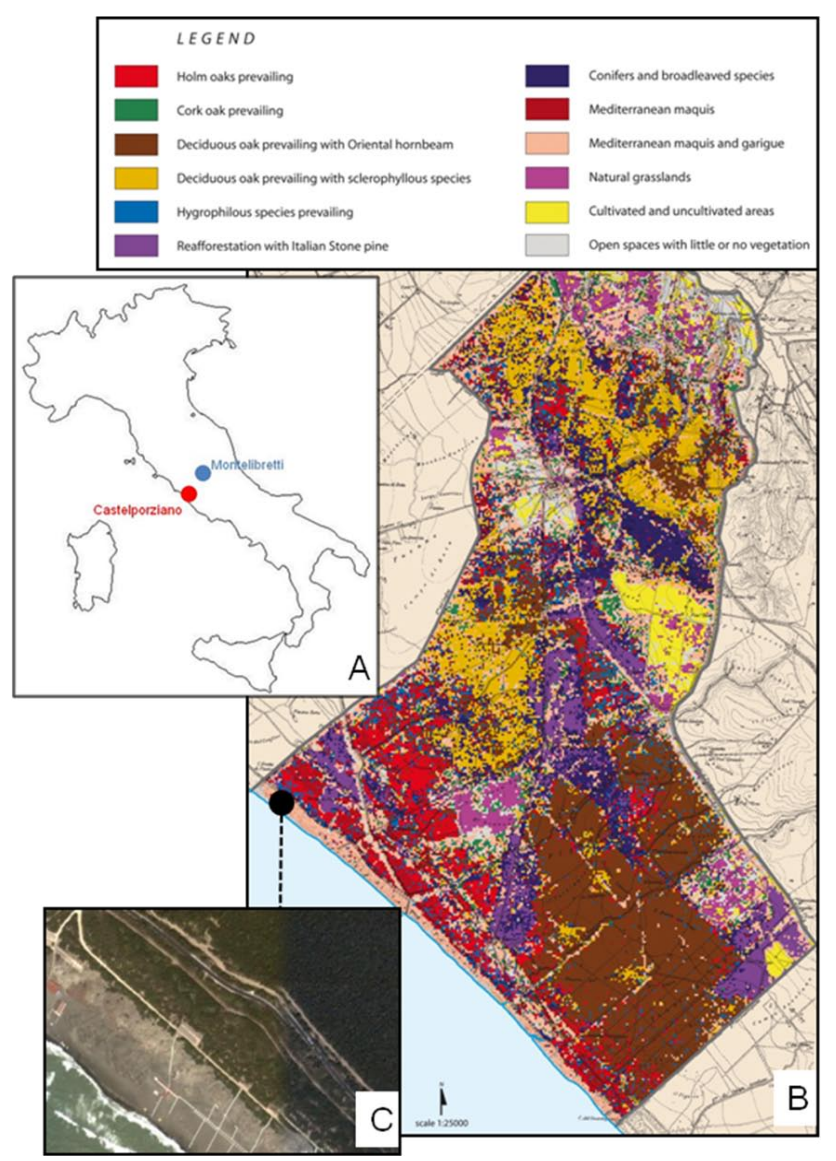

Fig. 1. Overview of the experimental site located in Castelporziano. In the sketch showing the Italian peninsula (A), the red circle identifies the Castelporziano Estate $\left(41^{\circ} 41^{\prime} 54.56^{\prime \prime} \mathrm{N}, 12^{\circ} 21^{\prime} 9.50^{\prime \prime} \mathrm{E}\right)$, an area of about 6000 ha located in the Lazio region, $25 \mathrm{~km} \mathrm{SW}$ from the center of Rome; the blue circle identifies the CNR Research station in Montelibretti $\left(42^{\circ} 6^{\prime} 26.82^{\prime \prime} \mathrm{N}, 12^{\circ} 38^{\prime} 15.79^{\prime \prime} \mathrm{E}\right)$ The Castelporziano area is enlarged in $(\mathbf{B})$. A legend explains the different vegetational types co-occurring in the estate. The black circle at the bottom left of panel (B) shows the specific location of the experimental site. Finally, panel $(\mathbf{C})$ is an aerial picture of the experimental site, showing the coast (bottom left), the sand dune strip, the strip of Mediterranean maquis and garigue, surrounded by communication roads where the campaign took place (center), and the dense Meditterranean maquis (top right).

scaffold where the monitoring devices were positioned was carried out during May. The projected area $\left(P A-\mathrm{m}^{2}\right)$ of the crown of each individual plant ( $n=12-17$ per species) was obtained by measuring the crown radius along the four cardinal axes and averaging the four resulting areas. The sapwood area $\left(\mathrm{SA}-\mathrm{m}^{2}\right)$ was assessed by measuring the stem diameter at $10 \mathrm{~cm}$ from the ground on each species, after the cork and phloem were removed, in order to obtain a species-specific sapwood area to projected area ratio (SA/PA). These samples were collected outside the plot in order to avoid woundinduced isoprenoids emissions inside the footprint of the experimental area.
When it was not possible to distinguish to which stem the crowns of plants belonged, height and projected area were measured for the whole patch belonging to the same species. The percentage of soil covered (cover) by each species was obtained dividing the sum of the PA of each species by the area of the experimental plot.

The basal area of each species was calculated by:

$\mathrm{BA}=\frac{\mathrm{SA}}{\mathrm{PA}} \times$ cover

The leaf area of twenty leaves $\left(\mathrm{La}_{l}\right)$ per woody species collected from different plants was measured by computer software (Image Tool Software Roswell, GA). These leaves were dried at $80^{\circ} \mathrm{C}$ for a week to obtain the leaf mass (LM $-\mathrm{g})$. The leaf mass to area ratio $\left(\mathrm{LMA}-\mathrm{g} \mathrm{m}^{2}\right)$ of each leaf was calculated by:

$\mathrm{LMA}=\frac{\mathrm{La} l}{\mathrm{LM}}$

The leaf area (LA) to sapwood area ratio (LA/SA) of each species was estimated as the slope of the linear fit of the $\mathrm{LA}_{b}$ vs. SA regression using thirty branches for each species with diameters ranging between 0.3 and $5 \mathrm{~cm}$. The leaves of each branch were dried to obtain the total leaf material $\left(\mathrm{LM}_{\mathrm{tot}}-\right.$ $\mathrm{g})$ of the branch. The leaf area of each branch $\left(\mathrm{LA}_{b}\right)$ was estimated by multiplying $\mathrm{LM}_{\text {tot }}$ by the LMA:

$\mathrm{LA}_{b}=\mathrm{LM}_{\mathrm{tot}} \times \mathrm{LMA}$

The leaf area index (LAI) of Quercus ilex, Phillyrea latifolia, Arbutus unedo, and Erica arborea plants was derived by dividing the LA/SA ratio by the Projected Area (PA)/SA ratio:

$\mathrm{LAI}=\frac{\mathrm{LA}}{\mathrm{PA}}=\frac{\mathrm{LA}}{\mathrm{SA}} \times \frac{\mathrm{SA}}{\mathrm{PA}}$

The LAI of each species was estimated as the average LAI calculated on at least ten different plants per species. The LAI of Cistus incanus, Rosmarinus officinalis and Erica multiflora was assessed in a different way because of the elevated number of stems. For these species the LAI was obtained by multiplying the LMA by the dry weight of the leaves present over $0.25 \mathrm{~m}^{2}$ of soil (three samples for each species).

\subsection{Measurements of plant physiological properties and isoprenoids emission}

The measurements were performed during the month of May and in the central hours of the day (11:00 a.m.-03:00 p.m.). Photosynthesis, stomatal conductance and transpiration of all species were measured with a Li-6400-40 gas exchange open portable system (LI-COR, Lincoln, Neb., USA). A leaf was enclosed in a $6 \mathrm{~cm}^{2}$ cuvette and an air flow was pumped to the cuvette after being filtered with an active carbon cartridge to scavenge pollutants or BVOC present in the air. The instrument allowed to control light intensity and leaf temperature, 
which were set, respectively, at $1000 \mu \mathrm{mol} \mathrm{m}^{-2} \mathrm{~s}^{-1}$ of PAR (Photosynthetic Active Radiation) and $30^{\circ} \mathrm{C}$. These are the basal conditions at which isoprenoid emission is commonly measured (Guenther et al., 1995). The outlet from the cuvette was diverted to the Li-6400-40 infrared gas analyzer to measure $\mathrm{CO}_{2}$ and $\mathrm{H}_{2} \mathrm{O}$ exchange. These exchange rates were recorded after an adaptation period of around $1 \mathrm{~h}$ after leaf enclosure, and in any case after stabilization of the photosynthetic parameters. The outlet of the cuvette was then diverted to a glass traps ( $16 \mathrm{~cm}$ in length, $4 \mathrm{~mm}$ I.D.) filled with $130 \mathrm{~g}$ Tenax GC,20-35 mesh, (Alldrich, USA) and $115 \mathrm{~g}$ Carbograph 1, 20-40 mesh, (LARA S.p.A., Rome, Italy) to collect BVOC. Air was passed through the trap at a flow rate of $200 \mathrm{ml} \mathrm{min}^{-1}$, controlled by a pump (Pocket pump, SKC, PA, USA), until a total volume of $10 \mathrm{~L}$ of air was collected. Before measuring each individual leaf, emissions from the empty cuvette were also measured, to make sure that no enclosure contaminants were recorded.

Traps were stored in a refrigerated container until analyzed at CNR laboratory with a gas chromatograph (GC 5890, Hewelett Packard, Palo Alto, CA, USA) connected to a quadrupole mass spectrometer (MSD 5970, Hewelett Packard, Palo Alto, CA, USA). Traps were desorbed by keeping them at a temperature of $250^{\circ} \mathrm{C}$ for 5 min using helium as carrier gas at a flow rate of $20 \mathrm{ml} \mathrm{min}^{-1}$. Desorbed isoprenoids were concentrated in an empty liner at $-190^{\circ} \mathrm{C}$ under liquid nitrogen and then injected into the GC column by rising the temperature of the liner to $200^{\circ} \mathrm{C}$ in $5 \mathrm{~s}$. A Chrompack, fused silica capillary column $(50 \mathrm{~m}$ in length with $0.4 \mathrm{~mm}$ I.D.) coated with a $0.32 \mu \mathrm{m}$ of CPsil5 (Middelburg, The Netherlands) was used for the chromatographic separation. The elution was carried out by rising the column temperature from 50 to $250^{\circ} \mathrm{C}$ at a rate of $5^{\circ} \mathrm{C} \mathrm{min}^{-1}$. Compounds were identified and quantified following the procedure described in Ciccioli et al. (2002).

\subsection{Artificial irrigation on Cistus incanus plants}

A $20 \mathrm{~m}^{-2}$ area with Cistus incanus plants was located in the same experimental area. It was $500 \mathrm{~m}$ distant from the main experimental site, but with identical climatic and vegetation characteristics. This area was used to artificially irrigate plants, in order to better assess whether a droughtstress was causing physiological effects during the experimental period. This area was far enough not to interfere with the micrometeorological measurements of the main site (see Davison et al., 2009). Plants were irrigated daily in the early morning. Irrigation started two weeks before the exprerimental measurements at the main site, and continued throughout the campaign. The measurements of physiological traits and isoprenoid emission, as detailed above, were also performed on the plants of this plot.
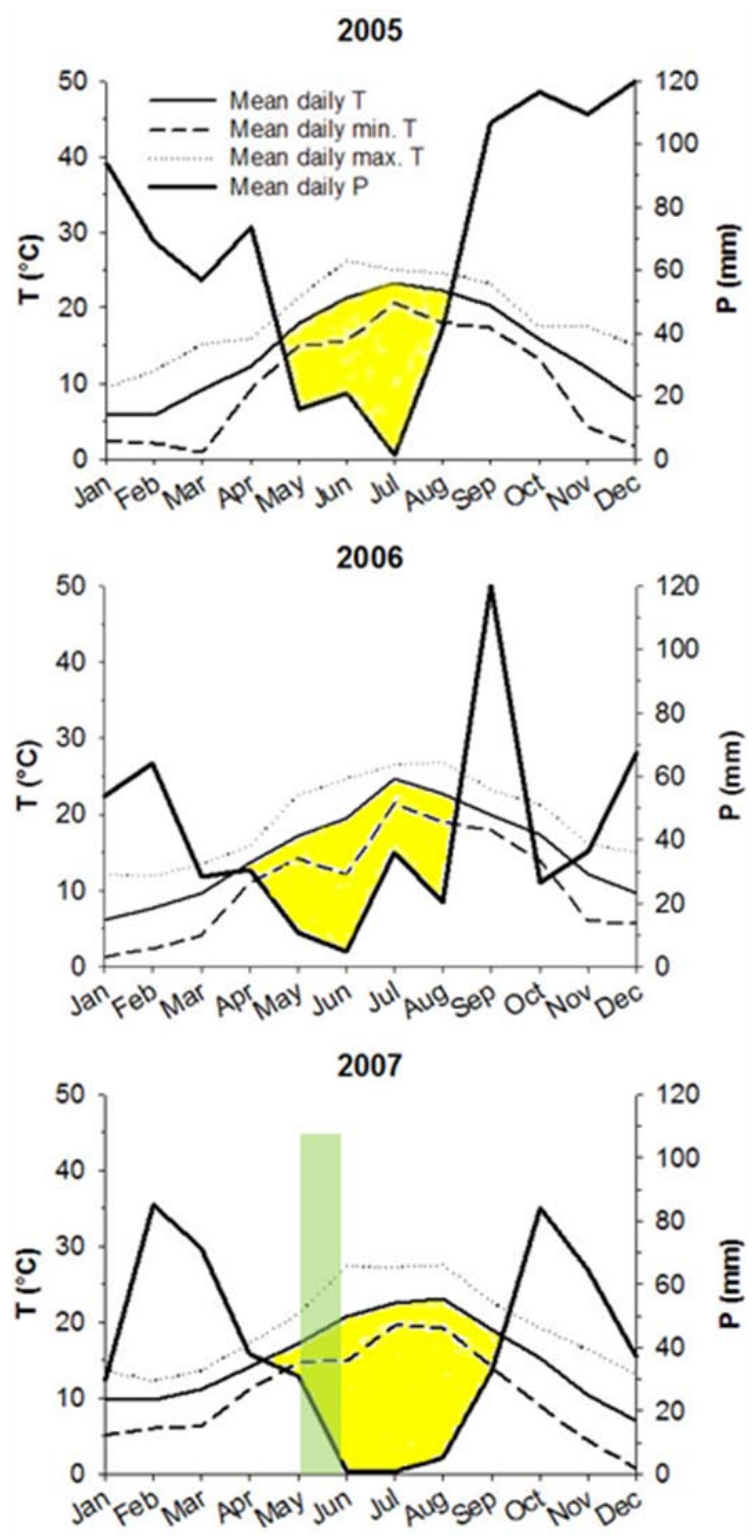

months

Fig. 2. Bagnouls Gaussens diagrams for the years 2005, 2006, 2007 at Castelporziano Estate. 14 Monthly temperatures ( $T$, left axis, $\left.{ }^{\circ} \mathrm{C}\right)$ are shown as daily mean (solid line), daily maximum 15 (dotted pattern) and daily minimum (dashed pattern). The sum of monthly rainfall ( $P$, right axis, $16 \mathrm{~mm})$ is also reported for the same periods. The yellow zone represents a drought period. The green 17 bar in the 2007 graph indicates the period of the campaign.

\section{Results and discussion}

\subsection{Climate and meteorological data}

Meteorological data for the years 2005-2007 showed that the climate of the site is typically Mediterranean with mean monthly temperatures ranging between a minimum of $4{ }^{\circ} \mathrm{C}$ 
and a maximum of $27^{\circ} \mathrm{C}$, extreme summer temperatures occasionally exceeding $30^{\circ} \mathrm{C}$ (maximal values of $32^{\circ} \mathrm{C}$ in August 2007), absence of freezing events, and a pronounced summer drought, with rainfall events concentrated in autumn and spring. In particular, the mean annual precipitation over the years 2005-2007 was $713 \mathrm{~mm}$, but only $480 \mathrm{~mm}$ were recorded during 2007 . The summer dry period was recorded on each one of the three years, with low monthly rainfalls $(<60 \mathrm{~mm}$ in the May-August period) as clearly shown in Bagnouls-Gaussen's diagrams (Bagnouls and Gaussen, 1957) (Fig. 2). The Mitrakos' MCS diagram showed an evident cold stress period in our experimental site from November to March (Fig. 3). More interestingly, the MDS index showed that drought stress was widespread over the entire dry seasons, but was particularly strong during the summer periods of years 2006 and 2007 (Fig. 3). Drought causes a severe stress in warm Mediterranean seasons, when high temperatures induce high evapotranspiration, with fast depletion of water reservoirs in the soil and in plant tissues. This explains the evolution of the "water saving" strategy, also observed in our measurements with dune species, which allows to slow down the main metabolic functions, and reduce water loss through stomata during summers.

The year 2007 was in general very warm, with prolonged drought stress also in winter, and monthly precipitation never exceeding $100 \mathrm{~mm}$ (Fig. 2). All climatic indices confirmed that the period of the campaign (May 2007) was favourable to vegetative growth, at least when compared to the hot and dry summer. Moreover, the proximity of the site to the sea led to a high humidity regime (with RH rarely below 60\%) with formation of dew in the night-time.

Daily variations of the main meteorological parameters recorded in Castelporziano during the field campaign are shown in Fig. 4a to d, and consistently indicate that the weather was characterized by a certain variability, more typical of earlier spring periods. High pressure periods were frequently alternated to short low pressure episodes, and particularly important was the low pressure episode occurring on 28 May because it was associated to a front of humid air that generated strong winds blowing from the SW-W sector. Precipitations occurred also at the beginning of the campaign (4 May), but in this case the front was less intense and characterized by light winds blowing from the same sector as during the rest of the campaign. During low pressure episodes, a synoptic scale circulation drove the movement of the air masses. During high pressure periods, however, the circulation was mostly determined by a local sea-land breeze wind regime, with moderate to strong S-SW winds blowing during the day, and light N-NE winds after 02:00 a.m. (Figs. 4c and 5a). As already observed in previous campaigns (Kalabokas et al., 1997), the sea-land breeze regime generates a transport of biogenic emission toward the city of Rome during the day, but allows also primary (such as $\mathrm{VOC}, \mathrm{NO}_{\mathrm{x}}$ ) and secondary pollutants (such as ozone and PAN), respectively emitted and produced in the urban area of Rome, to reach
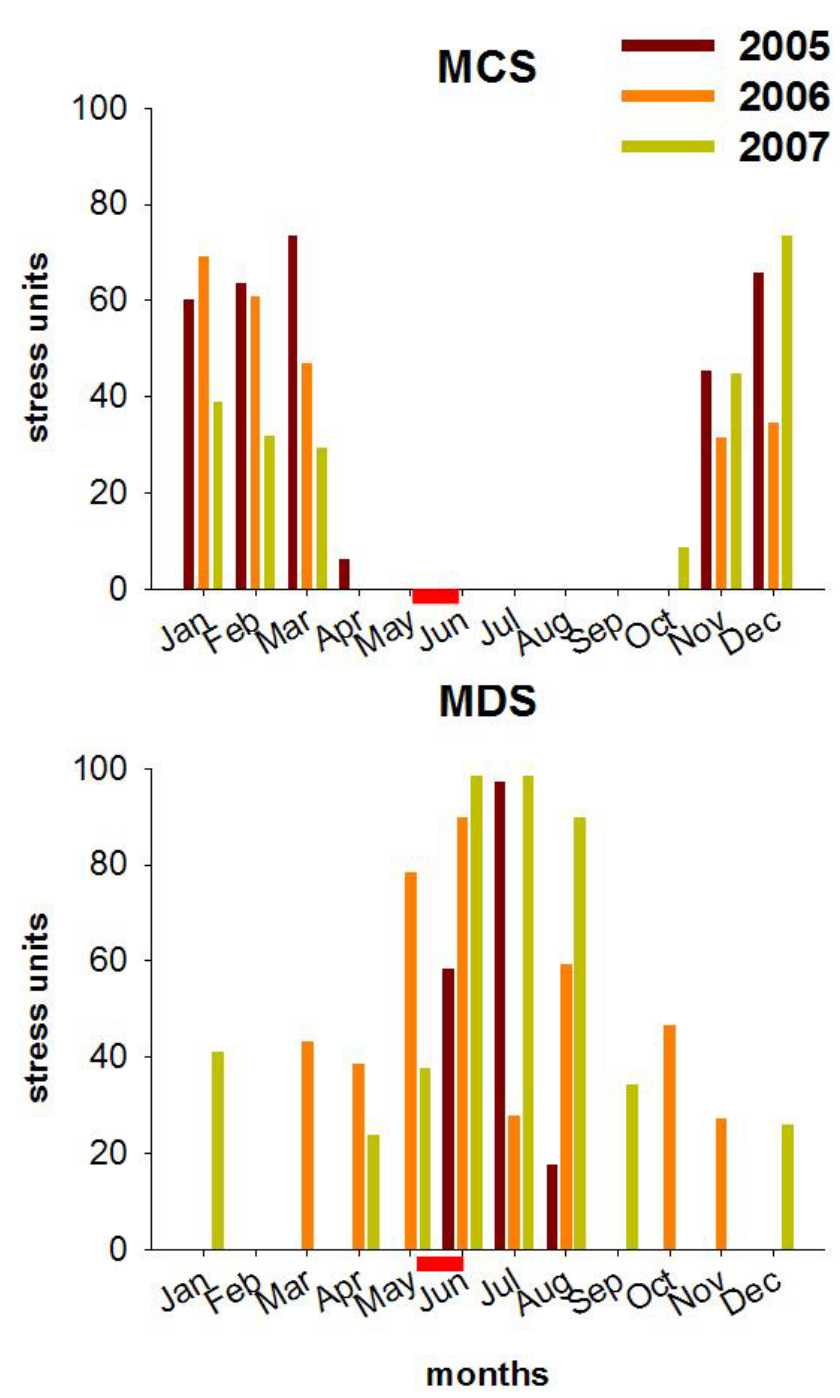

Fig. 3. Mitrakos diagrams for monthly cold stress (MCS) and monthly drought stress (MDS) in the years 2005 (brown bars), 2006 (orange bars), 2007 (green bars) at Castelporziano Estate. The red line in correspondence of May and June indicates in the x-axes the the period of the campaign.

Casteporziano at night, between 02:00-03:00 and 09:00 a.m. For most of the time the maximum air daily temperature ranged between 25 and $26^{\circ} \mathrm{C}$ and only in one day values of $30^{\circ} \mathrm{C}$ were reached. Because of these meteorological conditions, the vegetation of the sandy dunes never really reached stress conditions typically observed during summer, and gasexchanges of $\mathrm{CO}_{2}, \mathrm{H}_{2} \mathrm{O}$ and $\mathrm{BVOC}$ were not limited.

\subsection{Ozone levels during the field campaign}

The duration of high pressure periods (3-5 days, Fig. 4a) did not allow to generate the high levels of ozone typically observed in Castelporziano during summer (Kalabokas et al., 1997). As several studies performed in the Mediterranean 

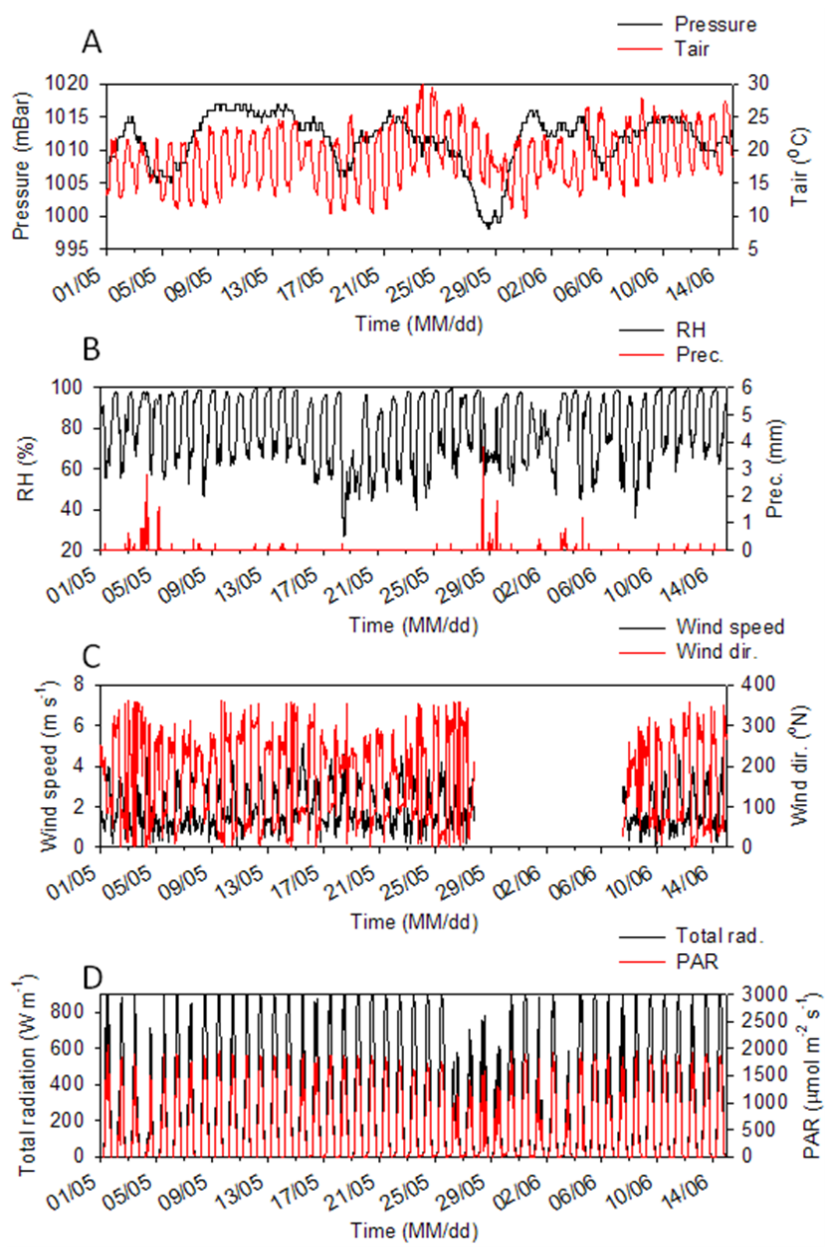

Fig. 4. Daily profiles of the meteorological parameters collected at two stations inside the Castelporziano estate. The Tor Paterno station was located $6 \mathrm{~km}$ to the south of the experimental site, but at a similar distance from the coast. The Carboeurope station (serving the Carboeurope-IP European project, and managed by the University of Tuscia) was located $500 \mathrm{~m} \mathrm{NE}$ from the sandy dune site. Panel (A) shows pressure and air temperature at Tor Paterno site, panel (B) shows relative humidity and precipitation at Tor Paterno, panel (C) shows wind speed and direction at the Carboeurope station, panel (D) shows the total radiation and PAR (photosynthetically active radiation) at the Carboeurope station.

coasts (Millan-Millan et al., 1998) have shown, high ozone levels occur during high pressure conditions, characterized by a local sea-land breeze circulation which last long enough to transport over the sea secondary pollutants generated in densely populated areas. Ozone formation is enhanced when air masses advected by the sea breeze penetrate deeply into the valleys and become progressively enriched in $\mathrm{NO}_{\mathrm{x}}$ and VOC emitted from urban areas. When moving out from these polluted areas, air masses become progressively depleted in $\mathrm{NO}_{\mathrm{x}}$. Under these NOx-limited conditions ozone production progressively decreases, although its content in the pol-
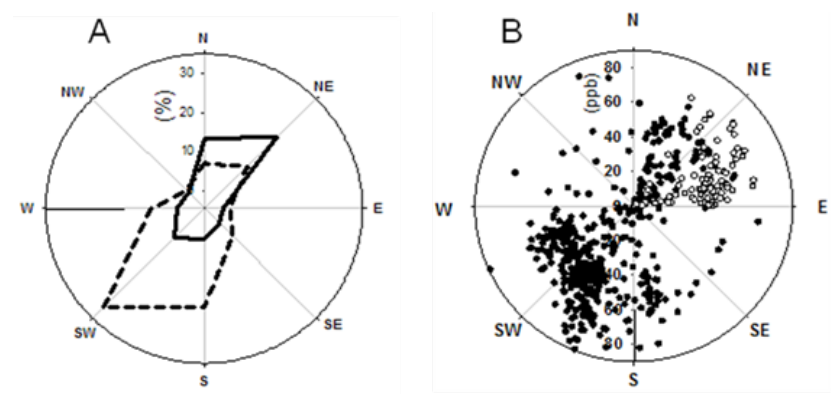

Fig. 5. Panel (A): Polar plot showing percentage of wind distribution during night (21:00-06:00, solid line) and day hours (06:0021:00, dashed line) in Castelporziano Estate, central Italy. Panel (B): Polar plot showing ozone concentration (ppbv) during day (black circles) and night hours (white circles) in the same experimental area.

luted plume remains high because little removal occurs by secondary reactions (Finnlayson-Pitts and Pitts, 1999). After reaching a mountain range, the air masses are conveyed back over the sea by a return flow, located above the advection flow and often separated from it from a shear layer (MillanMillan et al., 1998). Ozone present in the return flow can be transported up to $40 \mathrm{~km}$ over the sea, where it can stratify at night. After sunrise, the polluted layer containing the ozone transported from the city is mixed with the one resident below, resulting in an increase of ozone in the whole convective layer. When the sea breeze is activated (10:00-11:00 a.m.), ozone is driven back to the coast by advection (Millan-Millan et al., 1998). These effects have been also observed by Georgiadis et al. (1994) over the Adriatic sea. Such a continuous recirculation of ozone between the sea and inland sites where large emission of precursors take place causes a progressive increase in the ozone levels through all the areas interested by the air mass circulation, ultimately leading to photochemical smog episodes.

In the Tiber valley, the maximum ozone production usually occurs between the city limits of Rome and the suburban areas located $15 \mathrm{~km}$ from the city centre (Ciccioli et al., 1999). Under heavy smog conditions, the influx of the city plume of Rome gives rise to sharp peaks of ozone, peroxyacylnitrates (PAN), sulfates and nitrates in the suburban station of Montelibretti with maximum values that can be twice as high as those advected by the sea (Ciccioli et al., 1993, 1999; Cantuti et al., 1993). Ozone contained in these air masses is conveyed back to the Tyrrhenian sea by a return flow generated when they reach the Apennine range located 40-60 km from the coast (Baldi et al., 1993; Mastrantonio et al., 1994). The importance of the sea-land breeze regime in generating high levels of ozone in the area of Rome has been confirmed after application of the FARM model, whose results have been validated by field studies performed in different seasons (Gariazzo et al., 2007). These results show that in summer, when high pressure conditions last for more than 


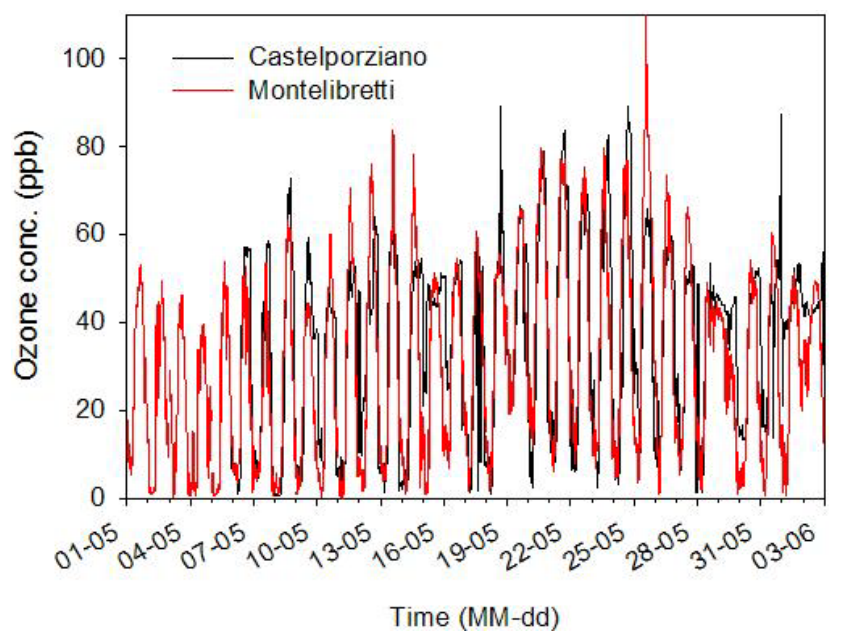

Fig. 6. Daily profiles of ozone levels in Castelporziano (ppbv), central Italy and at the EMEP station in Montelibretti, located NE of Castelporziano, $20 \mathrm{~km}$ downwind Rome, inside the Tiber valley. 30 min means are reported for the period from 1 May to 4 June 2007.

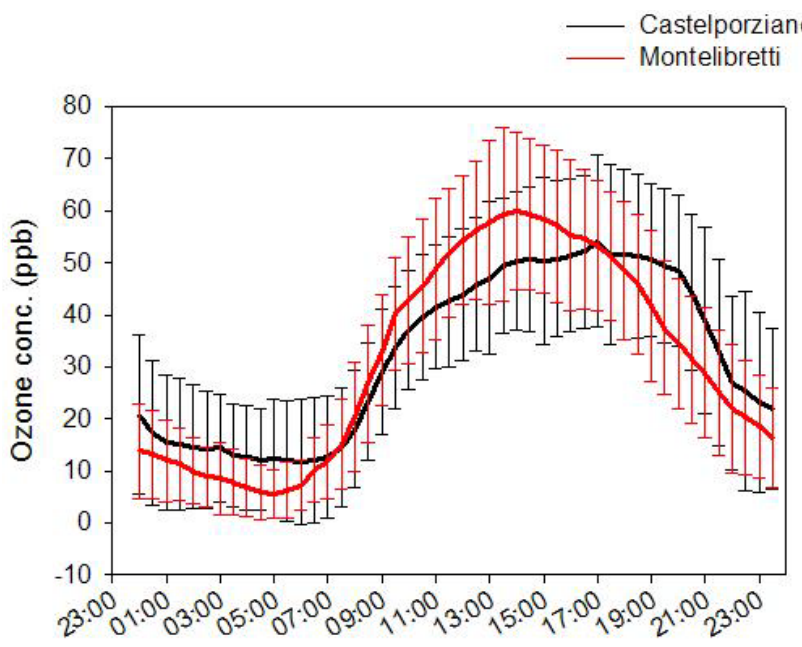

Hours of dav

Fig. 7. Half-hour averaged concentrations of ozone in Castelporziano (black line) and in Montelibretti (red line) for the period 1 May-4 June 2007. Mean \pm SD are reported ( $n=42$ days).

2 weeks, pollution generated in the area of Rome progressivelly increase the ozone levels present in the Tyrrhenian coast where Castelporziano is located.

Ozone data collected in Castelporziano and Montelibretti during the campaign (Fig. 6) show that differences in ozone concentrations between the two sites occurred only when high-pressure conditions were generated over the area. This conclusion is supported by the polar plots reported in Fig. $5 \mathrm{~b}$. During low pressure episodes, the ozone levels in the two sites were almost the same. This suggests that, during the campaign, stability conditions that characterized hot and sunny days did not last long enough to generate accumulation of large amounts ozone over the sea. Consequently, levels measured in Castelporziano never reached those measured in summer, when values up to $90-95$ ppbv have been recorded (Kalabokas et al., 1997). The observation that the mean daily ozone profile recorded in Castelporziano does not show the same bell-shaped profile of temperature and solar radiation which characterizes the suburban site of Montelibretti (Fig. 7), indicates that transport from aged air masses accumulated over the sea was the main source for this pollutant over the coast. Data in Fig. 7 also show that night time levels of ozone were often higher in Castelporziano than in Montelibretti. Under stable atmospheric conditions such difference may be explained by the higher $\mathrm{NO}$ emission from traffic over the Tiber valley than near the coast, as $\mathrm{O}_{3}$ is more efficiently removed from the lower layer by reaction with NO. As indicated by Fig. 5b, ozone advection caused by the land breeze could have also played a role in determing the ozone levels after 03:00 a.m.

\subsection{Vegetation characteristics}

The dune vegetation of the experimental site is composed of patches of Mediterranean "maquis" and "garigue". Following the nomenclature suggested by Pignatti (Pignatti et al., 2001), we named "garigues" the Erico-Rosmarinetum formation, characterized by the abundant presence of low-shrubs species as Rosmarinus officinalis, Erica multiflora, Arbutus unedo, Phillyrea latifolia and Cistus incanus albidus. Many of these species are typically located over Regosols soils rich of $\mathrm{CaCO}_{3}$ from deposited bioclasts. The woody species of this formation are rarely taller than two meters (Table 1). The Mediterranean "maquis" is a variation of the Quercetumilicis (Pignatti et al., 2001), which is dominated by Quercus ilex from the early developing stages. The early stages of "maquis" are formed by a mixture of Quercus ilex and other co-dominant species: Erica arborea, Phillyrea latifolia, Juniperus spp. and Arbutus unedo, with canopies rarely taller than five meters. The increase of below-ground marine water level could lead to a progressive replacement of high "maquis" with plant communities more typical of a degraded "garigue" (e.g. the Erico-Rosmarinetum), characterized by low shrubs adapted to very alkaline $\mathrm{pH}$ soils. Pignatti et al. (2001) hypothesized that vegetation patches of the two formations (garigue and maquis) observed in the experimental area correspond to an uneven distribution of sea shells which originated the bioclasts. Future studies should test this hypothesis.

As shown in Table 1, Quercus ilex was the tallest plant at the site, reaching the maximum of $3 \mathrm{~m}$ height. Arbutus unedo has the largest cover (21.9\%), followed by Rosmarinus officinalis (17.2\%), Quercus ilex (14.6\%), Phillyrea latifolia (14\%) and Erica multiflora (12.3\%). The summed percentage coverage shows that the "garigue" $(48.2 \%$ of 
Table 2. Measurements of isoprenoids emitted by the different plant species of the dune vegetation of the experimental area of Castelporziano, Rome, central Italy. Photosynthesis and stomatal conductance are also reported. Missing values are undetected compounds. All values indicates means $(n=4)$, standard deviations are reported in parenthesis for isoprene, total of monoterpenes, photosynthesis and stomatal conductance.

\begin{tabular}{|c|c|c|c|c|c|c|c|c|c|}
\hline Isoprenoids $\left(u g(C) g^{-1} D W h^{-1}\right)$ & Quercus ilex (mature leaves) & Quercus ilex (young leaves) & Cistus spp. (control) & Cistus spp. (irrigated) & Arbutus unedo & Phyllirea latifolia & Rosmarinus officinalis & Erica multiflora & Juniperus oxycedrus \\
\hline Isoprene & $0.33(0.54)$ & $0.31(0.4)$ & $0.05(0.04)$ & $0.38(0.91)$ & $0.02(0.02)$ & $0.05(0.04)$ & $0.02(0.01)$ & $1.48(0.4)$ & $0.02(0.01)$ \\
\hline Tricyclene & 0.01 & 0.02 & - & - & - & - & 0.12 & - & 0.02 \\
\hline alpha-Thujene & 0.05 & 0.07 & - & - & - & - & 0.12 & - & 0.01 \\
\hline alpha-Pinene & 2.39 & 3.58 & 0.18 & 0.31 & 0.04 & 0.23 & 2.44 & 0.29 & 5.54 \\
\hline Camphene & 0.09 & 0.14 & 0.01 & 0.02 & - & 0.01 & 2.81 & 0.14 & 0.08 \\
\hline 6-metil-5 metil Eptane & 0.39 & 0.36 & 0.36 & 0.31 & 0.14 & 0.32 & 0.56 & 0.54 & 0.37 \\
\hline Sabinene & 1.66 & 2.29 & 0.14 & 0.12 & 0.02 & 0.09 & 0.06 & 0.01 & 0.10 \\
\hline beta-Pinene & 1.65 & 2.43 & 0.12 & 0.17 & 0.03 & 0.11 & 4.09 & 0.26 & 0.19 \\
\hline Myrcene & 0.39 & 0.65 & 0.03 & 0.06 & 0.01 & 0.06 & 0.54 & 0.05 & 0.58 \\
\hline alpha-Phellandrene & 0.01 & 0.01 & - & - & - & - & 0.02 & - & 0.38 \\
\hline D-3-Carene & - & - & - & - & - & - & - & - & - \\
\hline alpha-Terpinolene & 0.01 & 0.02 & - & - & - & - & 0.04 & - & 0.01 \\
\hline para-Cymene & 0.02 & 0.02 & - & 0.01 & - & 0.01 & 0.07 & 0.01 & 0.04 \\
\hline 1,8-Cineol & 0.10 & 0.34 & 0.01 & 0.02 & - & 0.02 & 4.94 & 0.58 & 0.15 \\
\hline beta-Phellandrene & 0.09 & 0.08 & 0.01 & 0.04 & 0.01 & 0.01 & 0.03 & - & 1.50 \\
\hline Limonene & 0.22 & 0.26 & 0.09 & 0.28 & 0.05 & 0.09 & 1.41 & 0.18 & 0.19 \\
\hline cis-b-Ocimene & 1.77 & 0.03 & 0.04 & 0.23 & 0.00 & 0.03 & 0.25 & 0.03 & 0.02 \\
\hline trans-b-Ocimene & 0.52 & 0.02 & 0.02 & 0.07 & 0.01 & 0.02 & 0.06 & 0.16 & 0.09 \\
\hline gamma-Terpinolene & 0.02 & 0.04 & - & - & - & - & 0.10 & 0.01 & 0.01 \\
\hline Terpinolene & 0.01 & 0.02 & - & 0.01 & - & - & 0.04 & 0.01 & 0.11 \\
\hline Linalool & - & 0.01 & - & - & - & - & 0.07 & 0.01 & 0.00 \\
\hline 4-Terpineol & - & - & - & - & - & - & 0.18 & 0.03 & 0.00 \\
\hline$a+g$-Terpineol & - & 0.02 & - & - & - & - & 0.47 & 0.09 & 0.13 \\
\hline trans-b-Caryophyllene & - & - & - & - & - & - & 0.46 & - & - \\
\hline Total of Monoterpenes & $9.39(4.5)$ & $10.4(1.91)$ & $1.01(0.7)$ & $1.66(1.00)$ & $\mathbf{0 . 2 9}(0.20)$ & $0.98(0.30)$ & $18.89(5.00)$ & $2.40(1.00)$ & $9.57(2.50)$ \\
\hline Photosynthesis $\left(\mu \mathrm{mol} \mathrm{m}^{-2} \mathrm{~s}^{-1}\right)$ & $\mathbf{5 . 2 8}(0.75)$ & $3.2(0.60)$ & $10.41(1.09)$ & $14.35(1.25)$ & $9.22(0.97)$ & $5.35(2.61)$ & $8.58(1.00)$ & $0.48(0.10)$ & $6.73(1.20)$ \\
\hline Stomatal conductance $\left(\mathrm{mol} \mathrm{m}^{-2} \mathrm{~s}^{-1}\right)$ & $0.03(0.001)$ & $0.038(0.01)$ & $0.1245(0.02)$ & $0.204(0.04)$ & $0.0994(0.02)$ & $0.073(0.05)$ & $0.111(0.06)$ & $0.012(0.008)$ & $0.056(0.02)$ \\
\hline
\end{tabular}

the site) was slightly more widespread than the "maquis" (42.1\% of the site). In terms of LAI, species as Erica arborea $\left(4.5 \mathrm{~m}^{2} \mathrm{~m}^{-2}\right)$, Arbutus unedo $\left(2.9 \mathrm{~m}^{2} \mathrm{~m}^{-2}\right)$, Quercus ilex $\left(2.9 \mathrm{~m}^{2} \mathrm{~m}^{-2}\right)$, Rosmarinus officinalis $\left(2.5 \mathrm{~m}^{2} \mathrm{~m}^{-2}\right)$ mostly contributed to the average LAI of the site, which was $2.3 \mathrm{~m}^{2} \mathrm{~m}^{-2}$. Only $5 \%$ of the experimental site was constituted by bare soil, and another 5\% was covered with dead plant materials, i.e. fallen branches and leaves of annual herbs.

Changes in quality and depth of the water table of the sandy dune ecosystem can strongly affect biosphereatmosphere exchanges. The waterpools present in the experimental site have an important ecological role, since they preserve a high floral and faunal biodiversity. However, a dramatic decrease of the water table level was observed in the last years (Bucci, 2006). This process is very common in the Mediterranean coastal areas, being caused mostly by increasing water demand by agricultural activities and coastal inurbation. As a consequence, marine water infiltrates on the freshwater table, reaching more superficial levels and salinizing the root environment of dune and retrodune plants. If this occurs, shrubs species belonging to the Erico-Rosmarinetum with a more superficial root system, could be favoured with respect to woody species. Models predict a complete salinization of the soil by 2050 (Bucci, 2006) for the coastal area of Castelporziano. We measured the depth of the water table two times, in the middle of the test site. The water table depth was found to be 210 and $290 \mathrm{~cm}$, respectively, when measured on 27 May and $4 \mathrm{Au}-$ gust. It is therefore hypothesized that the sinking depth of the water table could be the main cause of abiotic stress during the dry periods. A detailed study on water use under drought stress for the most representative species of the dune vegetation is proposed by Mereu et al., 2009. A strong physiological dependence of schlerophyllous plants on the freshwater table level was also observed, in our same experimental site, with a study of isotopic fractionation in xylematic water (Alessio et al., 2004). In particular, the shrubs examined in our study, and particularly A. unedo, P. latifolia and, Q. ilex, showed negative values of ${ }^{18} \mathrm{O}_{2}$ values of xylematic water that are associated with high discrimination $(\Delta)$ values, even under very dry conditions. This indicates low long-term water use efficiency, especially when compared to the opposite behaviour of some other dune species (e.g. Smilax aspera). Interestingly, no species of the coastal dune system used marine water or mixtures of marine and freshwater (Alessio et al., 2004), indicating that in this site marine intrusion was absent.

\subsection{Physiology}

Plants showed an excellent physiological status during the experimental period. Rates of photosynthesis and stomatal conductance measured in mid May (Table 2) were comparable to data reported in the literature for unstressed leaves and higher than rates measured at the same experimental site during previous campaigns held in full summer (Manes et al., 1997b).

Since the measured ozone levels often exceeded $40 \mathrm{ppb}$ during the day-time (Figs. 5, 6, 7), and this is considered a threshold after which plants can be damaged by the pollutant (UNECE 2004), we also checked for possible ozone injuries to vegetation. No reduction of chlorophyll content, photosynthesis, chlorophyll fluorescence, nor visible injuries that could be directly attributed to ozone damage were found (data not shown). Most of the schlerophyllous species growing in the experimental site (Quercus ilex, Arbutus unedo, 
Pistacia lentiscus) are known to be resistant to chronic or prolonged ozone exposures (Vitale et al., 2008; Nali et al., 2004). This can be attributed to: i) low stomatal opening which reduces the amount of ozone taken up by leaves (Loreto and Fares, 2007), especially when stomata are further shut down because of concurrent drought stress; ii) thick cuticular waxes and mesophylls that reduce non-stomatal ozone entry, and increase the chance of ozone reaction inside mesophyll before reaching target sensible organelles (Loreto and Velikova, 2001); iii) detoxification of ozone by reaction of the pollutant with BVOC (especially isoprenoids) emitted by plants. Loreto and Fares (2007) demonstrated that ozone damage is considerably reduced in high isoprenoid emitters, although ozone uptake is higher in these plants, and products of putative reactions of ozone with isoprenoids were not described in planta. Since many Mediterranean species do emit high levels of isoprenoids (see below and also Kesselmeier and Staudt (1999) for a comprehensive review), isoprenoids and other reactive molecules may be key players in driving ozone uptake and efficient detoxification thus limiting dangerous effects of pollution in peri-urban areas.

\subsection{Isoprenoid emission}

As also shown by photosynthesis measurements, plants were actively growing during the experimental campaign. Growth occurs only when environmental constraints are low, and, in dry ecosystems of the Mediterranean area, it takes place mostly in two flushes during spring and fall (Reichstein et al., 2002). High photosynthesis is expected to drive high emissions of BVOC during spring, as some of these compounds, such as the main volatile isoprenoids, are formed by carbon directly shunted from photosynthetic carbon metabolism (Sharkey and Yeh, 2001). However, a strong seasonality has been observed for many BVOC, constraining biosynthesis and emissions of these compounds during spring. Isoprene emission is under developmental control, being very low in expanding leaves, and uncoupled from photosynthesis development (Sharkey and Loreto, 1993). A seasonal pattern of monoterpene emissions was also observed to depend diurnally and seasonally from light and temperature (Sabillon and Cremades, 2001) and phenology (Staudt et al., 1997, 2000; Ciccioli et al., 2003). This is attributed to slow development of the capacity to synthesize isoprenoid synthases, the enzymes catalyzing the formation of isoprene (Wiberley et al., 2005) or monoterpenes (Fischbach et al., 2002). Thus, a low emission of isoprene and monoterpenes may be expected early in the season. However, Wiberley et al. (2005) pointed out that the development of the trait (i.e. the transcriptional and translational limitation to isoprene synthase biosynthesis) is in turn controlled by growth temperature. Therefore, in the Mediterranean area, whose climate is characterized by already rather high spring temperatures, a sustained emission of isoprenoids could be seen already in spring.
Table 2 shows that emission of isoprene was low in the Mediterranean dunal ecosystem, confirming data previously obtained by Owen et al. (1997) at the same site, and by the whole previous campaign in the Mediterranean area (BEMA, 1997). However, monoterpene emission by some dune plants was relevant, despite the early season of measurement. Quercus ilex, in particular, was confirmed to be a high monoterpene emitter, with $\alpha$ and $\beta$-pinene being the most emitted compounds. The total emission of monoterpenes by $Q$. ilex leaves was around $10 \mu \mathrm{g}(\mathrm{C}) \mathrm{g}^{-1} \mathrm{DW} \mathrm{h}^{-1}$, a rate comparable to what was found also in previous field measurements (Loreto et al., 2001a). Monoterpene emissions were about 30\% lower than those reported by Bertin and Staudt (1996) and Kesselmeier et al. (1997) in Castelporziano, but these other measurements were run in full summer (i.e. with higher temperatures and more complete leaf development) and on a different site, characterized by more structured soil and higher water availability.

In our measurements, both mature (second year) leaves, and young, still expanding leaves, emitted similar rates of total monoterpenes (Table 2), which suggests that the rate of biosynthesis and emission is not under developmental control, and that monoterpene emission is also rapidly induced in young leaves that were grown at rather elevated spring temperatures, confirming the indications of Wiberley et al. (2005). Interestingly, however, the composition of the emitted monoterpene blend was different in mature and developing $Q$. ilex leaves, with trans and cis- $\beta$-ocimene only emitted by mature leaves. We surmise that ocimene biosynthesis is under developmental control. Trans- $\beta$-ocimene seasonal emission was observed in pines (Loreto et al., 2000; Staudt et al., 2000). Emission of trans- $\beta$-ocimene and other acyclic monoterpenes may be also induced by herbivore feeding (Heil and Silva Bueno, 2007), and may therefore reveal induction caused by past stress occurrence in mature leaves. However, trans and cis- $\beta$-ocimene emissions were also measured in $Q$. ilex leaves that were grown in absence of abiotic and biotic stress (Loreto et al., 1996).

Rosmarinus officinalis and Juniperus oxycedrus also emitted monoterpenes at high rates, but with different emission patterns. $\beta$-Pinene and 1,8-cineol were the main compounds emitted by $R$. officinalis, whereas the emission of $J$. oxycedrus was mainly characterized by $\alpha$-pinene. The total monoterpenes emission by rosemary leaves was $18.89 \mu \mathrm{g}(\mathrm{C}) \mathrm{g}^{-1} \mathrm{DW} \mathrm{h}^{-1}$, by far larger than reported by Hansen et al. (1997). Contrary to $Q$. ilex, R. officinalis and $J$. oxycedrus store monoterpenes in large pools in specialized glandular organs (Ormeno et al., 2007; Salido et al., 2002). The emission by monoterpene-storing species is generally not light-dependent, and a long time is needed to extinguish the pool once biosynthesis has been turned off (Guenther et al., 1993). Llusiá and Penuelas (1998, 2000) observed that monoterpene emission by monoterpene storing species is more dependent on temperature than in nonstoring species, which may drive relevant summer emissions 
of monoterpenes, even when photosynthesis is environmentally constrained. These authors also found an accumulation of monoterpenes in storage organs of Mediterranean species at increasing drought conditions, with maximal levels in the autumn. These findings explain why in our measuring period we did not observe the maximal monoterpene emission, and indicate that higher emissions can be detected during warmer periods, when the pools of monoterpenes are completely filled. However, the temperature dependence of monoterpenes stored in pools is not always that high. For instance in Pinus pinea emission of stored monoterpenes is less dependent on temperature than emission of non-stored monoterpenes (Staudt et al., 1997). In addition, it should be mentioned that rough handling can drive large emissions from storage pools (Loreto et al., 2000). We paid special attention to avoid breakage of storage pools in our measurements, but cannot exclude altogether that some of the abundant emission observed were also contributed by unwanted mechanical stress (see also Davison et al., 2009).

Owen et al. (1997), reported Cistus spp. to be weak isoprene and monoterpenes emitters in the Castelporziano ecosystem. However, we found values of monoterpene emission $\left(1.35 \mu \mathrm{g}(\mathrm{C}) \mathrm{g}^{-1} \mathrm{DW} \mathrm{h}^{-1}\right)$ much larger than previously reported. Llusiá and Penuelas (2000) detected in Cataluna high emissions from Cistus incanus, more in line with our indications. Monoterpene emission by Cistus incanus is probably under seasonal control. The emission rates detected in our campaign from Cistus incanus leaves were more similar to rates measured in October than to those measured in May in Cistus incanus plants growing in the Pianosa island (Baraldi et al., 2001), but Llusiá and Penuelas (2000) also measured maximal emissions in May. The Pianosa experiment indicated a strong dependency of Cistus incanus emission on water availability, as October sampling was done after a period of rainfalls (Baraldi et al., 2001). Indeed, we observed a further increase of the emission of both isoprene ( $>80 \%$ ) and monoterpenes ( $>40 \%$ with respect to controls) in Cistus incanus plants that were artificially irrigated during our experiment. Since stomata opening should not regulate isoprenoid emissions, with few exceptions (Niinemets et al., 2004), our finding indicates a strong control of water availability over the synthesis of isoprenoids in this species. Recent research outlined that isoprenoid biosynthesis is resistant to drought stress (Pegoraro et al., 2004; Brilli et al., 2007), but after a threshold level of stress the isoprenoid formation is also inhibited (Brilli et al., 2007). This could be the case of Cistus spp. which are water-spending plants characterized by low stomatal control on water content, and very large changes of leaf water status. The "water-spending" strategy of this species seem to be successful in an environment subjected to fast changes of soil water content, as in sandy soils. However, the impact of these metabolic fluctuations on secondary metabolism leading to isoprenoid formation remains unknown.
A detectable emission of isoprene and monoterpenes was also observed from Erica multiflora leaves (1.48 and $2.4 \mu \mathrm{g}(\mathrm{C}) \mathrm{g}^{-1} \mathrm{DW} \mathrm{h}^{-1}$, respectively). Again, this is a higher emission than previously measured by Owen et al. (1997) at the same site. However, strong isoprene-emitters are characterized by rates of emissions ten times higher than in monoterpene emitters. Thus, on the basis of our spring measurements and of the summer measurements of Owen et al. (1997), E. multiflora can only be categorized as a low isoprene emitter.

The other two screened species emitted low amount of monoterpenes. The weak emission of monoterpenes by $\mathrm{Ar}$ butus unedo $\left(0.29 \mu \mathrm{g}(\mathrm{C}) \mathrm{g}^{-1} \mathrm{DW} \mathrm{h}^{-1}\right)$, was also observed by Owen et al. (1997), and Pio et al. (1993). Alessio et al. (2004) also reported inconspicuous emissions of isoprenoids by $\mathrm{Ar}$ butus unedo and Phillyrea latifolia. It is therefore confirmed that these plants do not have the capacity to produce and emit relevant amounts of isoprenoids.

After measuring the basal emission at leaf level of each representative species of the stand (Table 2), an upscaling procedure was developed to estimate isoprenoid emission at ecosystem level. The species representativeness, and the species-specific leaf biomass over the experimental site (the parameters shown in column 4 and 5 of Table 1) were considered. The basal emission of isoprene for the whole stand (normalized at $30^{\circ} \mathrm{C}$ and a light intensity of $1000 \mu \mathrm{mol}$ photons $\mathrm{m}^{-2} \mathrm{~s}^{-1}$, according to Guenther's algorithm, 1995) was $0.31 \mu \mathrm{g}(\mathrm{C}) \mathrm{g}^{-1} \mathrm{DW} \mathrm{h}^{-1}$. This emission is lower than the emission suggested for Mediterranean ecosystems by Guenther et al. (1995) $\left(16 \mu \mathrm{g}(\mathrm{C}) \mathrm{g}^{-1} \mathrm{DW} \mathrm{h}^{-1}\right)$ and by Owen et al. (1997) $\left(14.88 \mu \mathrm{g}(\mathrm{C}) \mathrm{g}^{-1} \mathrm{DW} \mathrm{h}^{-1}\right)$. It should be mentioned that these two studies concentrated on Mediterranean ecosystems more abundant of isoprene emitting species (Myrtus communis and Cistus spp.) than the dune ecosystem investigated here.

The same averaging procedure was adopted for monoterpenes, and yielded a basal emission rate of $4.7 \mu \mathrm{g}(\mathrm{C}) \mathrm{g}^{-1} \mathrm{DW} \mathrm{h}^{-1}$. For monoterpenes, Guenther et al. (1995) suggested a basal emission value of $1.2 \mu \mathrm{g}(\mathrm{C}) \mathrm{g}^{-1} \mathrm{DW} \mathrm{h}^{-1}$, and a similar indication was given by Owen et al. (1997) $\left(2.2 \mu \mathrm{g}(\mathrm{C}) \mathrm{g}^{-1} \mathrm{DWh}^{-1}\right)$. Thus it is concluded that the Mediterranean dune vegetation is an important source of monoterpene emission, and a less important source of isoprene emission than other Mediterranean ecosystems. Emissions are also likely different in the macchia ecosystems growing on a less sandy soil, under different water limitations, especially during summer. Our estimate about stand emission rate may be lower than actual if integrated over the whole vegetative period. It has been shown that isoprene emission is controlled by seasonal temperatures (Sharkey et al., 1999) and a similar control may also occur in monoterpene-emitters (Ciccioli et al., 2003). Unless emissions are drastically restrained by stress episodes (Baraldi et al., 2001; Loreto et al., 2001b) emissions of dune vegetation might therefore increase when 
the stand is exposed to high summer temperatures for long periods.

\section{Conclusions}

The experimental area of Castelporziano is an ideal site to test the interactions between biosphere and atmosphere in an environment that is made fragile by heavy anthropogenic pressure and by climate change drivers. This situation is unfortunately typical of the entire Mediterranean coastal area, where plant ecosystems are particularly perturbed by a combination of anthropic impacts and natural climate changes (van Der Meulen and Salaman, 1997; IPCC, 2007).

The interdisciplinary effort of the ACCENT-VOCBAS campaign was concentrated on studying the source strength of BVOC emitted by Mediterranean dune vegetation, and the impact of BVOC on the physical and chemical properties of the atmosphere. We characterized the weather, climate and vegetation properties at the site, providing indispensable information for the correct interpretation of the results obtained by teams participating to the campaign. We showed that the campaign was run under generally good weather conditions which made easier measurements of chemical species at ecosystem level, and inspection of their sources. Our measurements of ozone concentrations also showed a regular trend that could be interpreted on the basis of the available climatic information. The sea-land breeze circulation system was often activated, transporting precursors and products of photochemical pollution along the Thyrrenian coast of Latium. The levels of ozone advected from the sea were lower than those usually observed in the middle of the summer season when photochemical smog episodes often occur. The ozone profiles were characterized by a top-flat peak reaching the maximum values late in the afternoon.

Plants were in good physiological conditions during the campaign, and showed BVOC emission factors higher than previously reported and not constrained by stress effects. The dune vegetation was dominated by monoterpene emitting species, while isoprene emitters were scarcely represented. Monoterpene emission was already quite high during spring, when the biosynthesis of volatile isoprenoids is believed to be limited by developmental causes both in species that do not store or do store these compounds. It is suggested that during summer, the emission may further increase as temperature rises, except than in water-spending plants such as Cistus incanus.

These measurements might be of interest to construct inventories and models of isoprenoid emissions at the ecosystem level, since the Mediterranean ecosystem may escape the generalizations that volatile isoprenoids are dominated by isoprene emissions and are under strong developmental control. Finally, we set the background to upscale measurements from leaf to whole ecosystem level, and to interpret concurrent measurements of BVOC fluxes (Davison et al., 2009), ozone fluxes (Gerosa et al., 2009), particle formation.

Acknowledgements. The field campaign was supported by the VOCBAS and ACCENT/BIAFLUX programmes. We would also like to express our gratitude to the Scientific Committee of the Presidential Estate of Castelporziano and to its staff. We are particularly grateful to GianTommaso Scarascia Mugnozza and to Aleandro Tinelli. Dr Daniele Cecca assisted during the campaign, and to Roberto Moretti, provided environmental data. Ermenegildo Magnani, Giuseppe Santarelli and Leandro Brunacci assisted with the preparation of the campign and helped with field measurements. Riccardo Valentini and Luca Belelli of the University of Tuscia are kindly acknowledged for providing environmental data from the Carboeurope-IP station. Cinzia Perrino of CNR is also acknowledged for providing data on ozone concentration at the EMEP station of Montelibretti.

Edited by: A. Arneth

\section{References}

Alessio, G. A., De Lillis, M., Brugnoli, E., and Lauteri, M.: Water sources and water-use efficiency in Mediterranean Coastal Dune Vegetation, Plant Biol., 6, 350-357, 2004.

Atkinson, R. and Arey, J..: Gas-phase tropospheric chemistry of biogenic volatile organic compounds: a review, Atmos. Environ., 37(2), 197-219, 2003.

Bagnouls, F. and Gaussen, H.: Les climats biologiques et leur classification, Ann. Geogr., 66, 193-220, 1957.

Baldi, M., Colacino, M., and Dalu, G. A.: Isola di Calore a Brezza di Mare in area urbana: il caso dell'Area Romana, $1^{\circ}$ Italian Symposium on the Strategies and Techniques for the Monitoring of the Atmosphere, P. Ciccioli Editor, Società Chimica Italiana, Rome, Italy, 268-278, 1993.

Baraldi, R., Rapparini, F., Loreto, F., Pietrini, F., and Di Marco G.: Emissione di composti organici volatili dalla vegetazione della macchia mediterranea, Il progetto PianosaLab, Forum, Ed. Uni. Udinese, Udine, Italy, 51, 99, 2001.

BEMA: An European Commission project on biogenic emissions in the Mediterranean area, edited by: Seufert, G., Atmos. Env., 31, 1-256, 1997.

Bernetti, G.: La vegetazione forestale del bacino del Mediterraneo e le altre vegetazioni di tipo Mediterraneo, Italia Forestale e Montana LII, 6 469-471, 1997.

Bertin, N. and Staudt, M.: Effect of water stress on monoterpene emissions from young potted holm oak (Quercus ilex L.) trees, Oecologia, 107, 456-462, 1996.

Blasi, C.: Carta del fitoclima del Lazio (scala 1:250000) - Regione Lazio, Ass. agricoltura e foreste, caccia e pesca, usi civici, Università di Roma "La Sapienza", Dipartimento di Biologia Vegetale, Roma, Italia, 1993.

Brilli, F., Barta, C., Fortunati, A., Lerdau, M., Loreto, F., and Centritto, M.: Response of isoprene emission and carbon metabolism to drought in white poplar saplings, New Phytol., 175, 244-254, 2007.

Bucci, M.: Stato delle risorse idriche, in: Il sistema ambientale della tenuta presidenziale di Castelporziano: Ricerche sulla complessità di un ecosistema forestale costiero mediterraneo, edited 
by: Accademia Nazionale delle Scienze detta dei Quaranta, 2006.

Cantuti, V., Ciccioli, P., Cecinato, A., Brancaleoni, E., Brachetti, A., Frattoni, M., and Di Palo V.: PAN nella valle del Tevere, $1^{\circ}$ Italian Symposium on the Strategies and Techniques for the Monitoring of the Atmosphere, P. Ciccioli Editor, Società Chimica Italiana, Rome, Italy, 137-145, 1993.

Chameides, W. L., Lindsay, R. W., Richardson, J., and Kiang C. S.: The role of biogenic hydrocarbons in urban photochemical smog: Atlanta as a case study, Science, 241, 1473-1475, 1988.

Ciccioli, P., Brancaleoni, E., Frattoni, M., Cucinato, A., and Brachetti A.: Ubiquitous occurrence of semi-volatile carbonyl compounds in tropospheric samples and their possible sources, Atmos. Environ., 27(12), 1891-1901, 1993.

Ciccioli, P., Brancaleoni, E., and Frattoni, M.: Reactive Hydrocarbons in the atmosphere at urban and regional scale, in Reactive hydrocarbons in the atmosphere, edited by: Hewitt, N. C., Academic Press, 159-207, 1999.

Ciccioli, P., Brancaleoni, E. and Frattoni, M.: Sampling of atmospheric volatile organic compounds (VOCs) with sorbent tubes and their analysis by GC-MS, In Environmental Monitoring Handbook, edited by: Burden, F. R., Mc Kelvie, I., Forstner, U., and Guenther, A., Mc Graw-Hill, New York, USA, 21-85, 2002.

Ciccioli, P., Brancaleoni, E., Frattoni, M., Marta, S., Brachetti, A., Vitullo, M., Tirone, G., and Valentini, R.: Relaxed eddy accumulation, a new technique for measuring emission and deposition fluxes of volatile organic compounds by capillary gas chromatography and mass spectrometry, J. Chromatog., A, 985, 283-296, 2003.

Ciccioli, P., and Mannozzi, M.: High molecular weight carbonyls in Volatile Organic Compounds in the Atmosphere, R. Koppmann Editor, Blackwell Publishing Ltd, Oxford, 292-334, 2007.

Claeys, M., Wang, W., Ion, A. C., Kourtchev, I., Gelencsérb, A., and Maenhaut, W.: Formation of secondary organic aerosols from isoprene and its gas-phase oxidation products through reaction with hydrogen peroxide, Atmos. Environ., 38, 4093-4098, 2004.

Davison, B., Taipale, R., Langford, B., Misztal, P., Fares, S., Matteucci, G., Loreto, F., Cape, J. N., Rinne, J., and Hewitt, C. N. : Concentrations and fluxes of biogenic volatile organic compounds above a Mediterranean macchia ecosystem in Western Italy, Biogeosciences Discuss., 6, 2183-2216, 2009.

Finlayson-Pitts, B. J. and Pitts Jr., J. N.: Chemistry of the lower and upper atmosphere, Theory experiments and applications, Academic Press, San Diego, USA, 1999.

Fischbach, J., Staudt, M., Zimmer, I., Rambal, S., and Schnitzler, J. P.: Seasonal pattern of monoterpene synthase activities in leaves of the evergreen tree Quercus ilex, Physiol. Plant., 114, 3, 354360, 2002.

Francaviglia, R., Gataleta, L., Marchionni, M., Trinchera, A., Aromolo, R., Benedetti, A., Nisini, L., Morselli, L., Brusori, B., and Olivieri, P.: Soil quality and vulnerability in a Mediterranean natural ecosystem of Central Italy, in: Il sistema ambientale della tenuta presidenziale di Castelporziano: Ricerche sulla complessità di un ecosistema forestale costiero mediterraneo, edted by: Accademia Nazionale delle Scienze detta dei Quaranta, 2006.

Fuentes, J. D., Wang, D., and Gu, L.: Seasonal variations of isoprene emissions from a boreal forest, J. Appl. Meteorol., 38,
855-869, 1999.

Gariazzo, C., Silibello, C., Finardi, S., Radice, P., Piersanti, A.,Calori, G., Cucinato, A., Perrino, C., Nussio, F., Cagnoli, M., Pelliccioni, A., Gobbi, G. P., and Di Filippo, P.: A gas/aerosol air pollutants study over the urban area of Rome using a comprehensive chemical transport model, Atmos. Environ., 41, 7286-7303, 2007.

Georgiadis, T., Giovanelli, G., and Fortezza, F.: Vertical layering of photochemical ozone during land-sea breeze transport, Il Nuovo Cimento, 17, 371-375, 1994.

Gerosa, G., Finco, A., Mereu, S., Marzuoli, R., and Ballarin-Denti, A.: Interactions among vegetation and ozone, water and nitrogen fluxes in a coastal Mediterranean maquis ecosystem. Biogeosciences Discuss., 6, 1453-1495, 2009.

Guenther, A. B., Zimmerman, P. R., Harley, P. C., Monson, R. K., and Fall, R.: Isoprene and monoterpene emission rate variability: model evaluations and sensitivity analyses, J. Geophys. Res., 98D, 12609-12617, 1993.

Guenther, A., Hewitt, C. N., Erickson, D., Fall, R., Geron, C., Graedel, T., Harley, P., Klinger, L., Lerdau, M., McKay, W. A., Pierce, T., Scholes, B., Steinbrecher, R., Tallamraju, R., Taylor, J., and Zimmerman, P.: A global model of natural volatile organic compounds emissions, J. Geophys. Res., 100, 8873-8892, 1995.

Guenther, A., Karl, T., Harley, P., Wiedinmyer, C., Palmer, P. I., and Geron, C.: Estimates of global terrestrial isoprene emissions using MEGAN (Model of Emissions of Gases and Aerosols from Nature), Atmos. Chem. Phys., 6, 3181-3210, 2006,

http://www.atmos-chem-phys.net/6/3181/2006/.

Hansen, U., Van Eijk, J., Bertin, N., Staudt, M., Kotzias, D., Seufert, G., Fugit, J. L., Torres, L., Cecinato, A., Brancaleoni, E., Ciccioli, P., and Bomboi, T.: Biogenic emissions and $\mathrm{CO}_{2}$ gas exchange investigated on four Mediterranean shrubs, Atmos. Environ., 31, 157-167, 1997.

Heil, M. and Silva Bueno, J. C.: Within-plant signaling by volatiles leads to induction and priming of an indirect plant defense in nature, PNAS, 104(13), 5467-5472, 2007.

Kalabokas, P., Bartzis, J.C., Bomboi, T., Ciccioli, P., Cieslik, S., Dlugi, R., Foster, P., Kotzias, D., and Steinbrecher, R.: Ambient atmospheric trace gas concentrations and meteorological parameters during the first BEMA measuring campaign on May 1994 at Castelporziano, Italy, Atmos. Environ., 31, 67-77, 1997.

Karl, T.G., Spirig, C., Rinne, J., Stroud, C., Prevost, P., Greenberg, J., Fall, R., and Guenther, A.: Virtual disjunct eddy covariance measurements of organic compound fluxes from a subalpine forest using proton transfer reaction mass spectrometry, Atmos. Chem. Phys., 2, 279-291, 2002,

http://www.atmos-chem-phys.net/2/279/2002/.

Kesselmeier, J. and Staudt, M.: Biogenic Volatile Organic Compound (VOC): An overview on emission, physiology and ecology, J. Atm. Chem., 33, 23-88, 1999.

Iinuma, Y., Müller, C., Berndt, T., Böge, O., Claeys, M., and Herrmann, H.: Evidence for the existence of organosulfates from beta-pinene ozonolysis in ambient secondary organic aerosol, Environ. Sci. Technol., 19, 6678-6683, 2007.

INFC: Guida alla classificazione della vegetazione forestale. Inventario Nazionale delle Foreste e dei Serbatoi Forestali di Carbonio. MiPAF - Direzione Generale Risorse Forestali Montane Idriche Corpo Forestale dello Stato, CRA-ISAFA, Trento, 2003. 
IPCC: Climate change 2007: contribution of the three Working Groups to the fourth assessment report of the Intergovernmental Panel on Climate change, Cambridge University Press, 2007.

Lammel, G. and Cape, G. N.: Nitrous acid and nitrates in the atmosphere, Chem. Soc. Rev., 25(5), 361-369, 1996.

Lindinger, W., Hansel, A., and Jordan, A.: On-line monitoring of volatile organic compounds at pptv levels by means of ProtonTransfer-Reaction Mass Spectrometry (PTR-MS), Medical applications, food control and environmental research, Int. J. Mass Spectrom. Ion Proc., 173, 191-241, 1998.

Loreto, F., Ciccioli, P., Brancaleoni, E., Cecinato, A., Frattoni, M., and Sharkey, T.: Different sources of reduced carbon contribute to form three classes of terpenoid emitted by Quercus ilex L. Leaves, Proc. Natl. Acad. Sci., USA, 93, 9966-9969, 1996.

Loreto, F. and Delfine, S.: Emission of isoprene from salt-stressed Eucalyptus globulus leaves, Plant Physiol., 123, 1605-1610, 2000.

Loreto, F., Nascetti, P., Graverini, A., and Mannozzi, M.: Emission and content of monoterpenes in intact and wounded needles of the Mediterranean pine Pinus pinea, Funct. Ecol., 14, 589-595, 2000.

Loreto, F., Ferranti, F., Mannozzi, M., Maris, C., Nascetti, P., and Pasqualini, S.: Ozone quenching properties of isoprene and its antioxidant role in plants, Plant Physiol., 126, 993-1000, 2001a.

Loreto, F. and Velikova, V.: Isoprene produced by leaves protects the photosynthetic apparatus against ozone damage, quenches ozone products, and reduces lipid peroxidation of cellular membranes, Plant Physiol., 127(4), 1781-1787, 2001b.

Loreto, F., Fischbach, R. J., Schnitzler, J. P., Ciccioli, P., Brancaleoni, E., Calfapietra, C., and Seufert, G.: Monoterpene emission and monoterpene synthase activities in the Mediterranean evergreen oak Quercus ilex L. grown at elevated $\mathrm{CO} 2$ concentrations, Global Change Biol., 7, 709-717, 2001b.

Loreto, F. and Fares, S.: Is ozone flux inside leaves only a damage indicator? Clues from volatile isoprenoid studies, Plant Physiol.., 143, 1096-1100, 2007.

Loreto, F., Barta, C., Brilli, F., and Noguès, I.: On the induction of volatile organic compound emissions by plants as consequence of wounding or fluctuations of light and temperature, Plant, Cell Environ., 29, 1820-1828, 2006.

Llusià, J. and Peñuelas, J.: Changes in terpene content and emission in potted Mediterranean woody plants under severe drought, Can. J. Bot., 76, 8, 1366-1373, 1998.

Llusià, J. and Peñuelas, J.: Seasonal patterns of terpene content and emission from seven Mediterranean woody species in field conditions, Am. J. Bot., 87, 133-140, 2000.

Manes, F., Grignetti, A., Tinelli, A., Lenz, R., and Ciccioli, P.: General features of the Castelporziano test site, Atmos. Environ., 31, 19-25, 1997a.

Manes, F., Seufert, G., and Vitale, M.: Ecophysiological studies of Mediterranean plant species at the Castelporziano estate, Atmos. Environ., 31, 51-60, 1997b.

Mastrantonio, G., Viola, A.P., Argentini, S., Hocco, C., Giannini, L., Rossini, L., Abbate, G., Ocone, B., and Casonato, M.: Observation of sea breeze effects in Rome, Bound.-Lay. Meteorol., 71, 67-80, 1994.

Mereu, S., Salvatori, E., Fusaro, L., Gerosa, G., Muys, B., and Manes, F.: A whole plant approach to evaluate the water use of mediterranean maquis species in a coastal dune ecosystem,
Biogeosciences Discuss., 6, 1713-1746, 2009.

Mooney, H. A. and Dunn, E. L.: Photosynthetic Systems of Mediterranean-Climate Shrubs and Trees of California and Chile, The American Naturalist, 104, 447-453, 1970.

Maun, M.A.: Adaptations enhancing survival and establishment of seedlings on coastal sand dunes, Plant ecology, 111, Vol. I, 15735052, 1994.

Millan-Millan, M., Salvador, R., Mantella, E., and Artinano, A.: Meteorology of photochemical air pollution in Southern Europe: experimental results from EC research projects, Atmos. Environ., 30, 2583-2593, 1998

Mooney, H. A. and Dunn, E. L.: Convergent evolution of Mediterranean-climate evregreen sclerophyllous shrubs, Evolution, 24, 292-303, 1970.

Niinemets, U., Loreto, F., and Reichstein, M.: Physiological and physico-chemical controls on foliar volatile organic compound emissions, Trends Plant Sci., 9, 180-186, 2004.

Mitrakos, K.: A theory for Mediterranean plant life, Acta Oecol. Plant., 1, 245-252, 1980

Ormeño, E., Fernandez, C., and Mévy, J. P.: Plant coexistence alters terpene emission and content of Mediterranean species, Phytochemistry, 68, 6, 840-852, 2007.

Owen, S., Boissard, S., Street, R. A., Duckham, S. C., Csiky, O., and Hewitt, N.: Screening of 18 mediterranean plant species for volatile organic compound emission, Atmos. Environ., 31, 101117, 1997.

Nali, C., Paoletti, E., Marabottini, R., Della Rocca, G., Lorenzini, G., Paolacci, A., Ciaffi, M., and Badiani, M.: Ecophysiological and biochemical strategies of response to ozone in Mediterranean evergreen broadleaf species, Atmos. Environ., 38, 15, 22472257, 2004.

Pegoraro, E., Rey, A., Bobich, E. G., Barron-Gafford, G., Grieve, K. A., Malhi, Y., and Murthy, R.: Effect of elevated CO2 concentration and vapour pressure deficit on isoprene emission from leaves of Populus deltoides during drought, Funct. Plant Biol., 31, 1137-1147, 2004

Pignatti, S., Bianco, P. M., Tescarollo, P., and Scarascia Mugnozza, G. T.: La vegetazione della tenuta di Castelporziano, In: Il sistema ambientale della tenuta di presidenziale di Castelporziano, Accademia Nazionale dei Quaranta, "scritti e documenti" XXVI, Rome, Vol. II, 441-709, 2001.

Pinzari, F., Trinchera, A., Benedetti, A., and Sequi, P.: Use of biochemical indexes in the Mediterranean environment: comparison among soils under different forest vegetation, J. Microbiol. Meth., 36, 21-28, 1999.

Pio, C. A., Nunes, T. V., and Brito, S.: Volatile hydrocarbon emissions from common and native species of vegetation in Portugal. Air Pollution Research Report 47, Joint Workshop CEC/BIATEX of EUROTRAC, General assessment of biogenic emissions and deposition of nitrogen compounds, sulphur compounds and oxidants in Europe, 291-298, 1993.

Reichstein, M., Tenhunen, J. D., Roupsard, O., Orcival, J. M., Rambal, S., Miglietta, F., Peressotti, A., Pecchiari, M., Tirone, G., and Valentini, R.: Severe drought effects on Ecosystem $\mathrm{CO}_{2}$ and $\mathrm{H}_{2} \mathrm{O}$ fluxes at three Mediterranean evergreen sites: revision of current hypothesis?, Global Change Biol., 8, 999-1017, 2002.

Rinne, J., Guenther, A., Warneke, C., de Gouw, J. A., and Luxembourg, S. L.: Disjunct eddy covariance technique for trace gas flux measurements, Geophys. Res. Lett., 28, 3139-3142, 2001. 
Rosenstiel, T. N., Potosnak, M. J., Griffin, K. L., Fall, R., and Monson, R. K.: Increased $\mathrm{CO}_{2}$ uncouples growth from isoprene emission in an agriforest ecosystem, Nature, 421, 256-259, 2003.

Sabillon, D. and Cremades, L. V.: Diurnal and seasonal variation of monoterpene emission rates for two typical Mediterranean species (Pinus pinea and Quercus ilex) from field measurements - relationship with temperature and PAR, Atmos. Environ., 35, 26, 4419-4431, 2001.

Salido, S., Altarejos, J., Nogueras, M., Sánchez, A., Pannecouque, C., Witvrouw, P., and De Clercq, E.: Chemical studies of essential oils of Juniperus oxycedrus ssp. Badia, J. Ethnopharmacol., 81, 129-134, 2002.

Sharkey, T. D., and Yeh, S.: Isoprene emission from plants, Annual Rev. Plant Phys. Plant Mol. Biol., 52, 407-436, 2001.

Sharkey, T. D. and Loreto, F.: Water stress, temperature, and light effects on the capacity of isoprene emission and photosynthesis of kudzu laves, Oecologia, 95, 328-333, 1993.

Sharkey, T. D., Singsaas, E. L., Lerdau, M. T., and Geron, C. D.: Weather effect on isoprene emission capacity and applications in emission algorithms, Ecol. Appl., 9, 1132-1137, 1999.

Staudt, M., Bertin, N., Hansen, U., Seufert, G., Ciccioli, P., Foster, P., Frenzel, B., and Fugit, J. L.: Seasonal and diurnal patterns of monoterpene emissions from Pinus Pinea L., Atmos. Environ., 32, 145-156, 1997.

Staudt, M., Bertin, N., Frenzel, B., and Seufert, G.: Seasonal variation in amount and composition of monoterpenes emitted by young Pinus pinea trees - Implications for emission modelling, J. Atmos. Chem., 35, 77-99, 2000.

Thompson, J. D.: Plant Evolution in the Mediterranean, Oxford University Press, ISBN 0198515332, 2005.

Trinchera, A., Pinzari, F., Fiorelli, F., Marchionni, M., and Benedetti, A. Duna antica e duna recente: due ecosistemi a confronto, Bollettino della Società italiana di Scienze del Suolo, 48, 399-416, 1998.
UNECE: Revised manual on methodologies and criteria for mapping critical levels/loads and geographical areas where they are exceeded, www.icpmapping.org, 2004.

van der Meulen, F. and Salman, A. H. P. M.: Management of Mediterranean coastal dunes, Ocean Coast. Manage., 30, 177195, 1996.

Verheggen, B., Weingartner, E., Baltensperger, U., Metzger, A., Duplissy, J., Dommen, J., and Prévôt, A. S. H.: Aerosol Formation from Isoprene: Determination of Particle Nucleation and Growth Rates., Nucl. Atmos. Aerosol., 989-993, doi:10.1007/978-14020-6475-3, 2007.

Vitale, M., Salvatori, E., Loreto, F., Fares, S., and Manes, F.: Physiological responses of Quercus ilex leaves to water stress and acute ozone exposure under controlled conditions, Water Air Soil Poll., 189(1-4), 113-125, 2008.

Vitale, M., Matteucci, G., Fares, S., and Davison, B.: A processbased model to estimate gas exchange and monoterpene emission rates in the mediterranean maquis - comparisons between modelled and measured fluxes at different scales, Biogeosciences Discuss., 6, 1747-1776, 2009.

Vickers, C. E., Possel, M., Cojocariu, C. I., , Velokova, V. B., , Wornkitkul, J. L., Ryan, A., Mullineaux, P. M, and Hewitt, N.: Isoprene synthesis protects transgenic tobacco plants from oxidative stress, Plant Cell Environ., 32, 520-531, 2009.

Wiberley, A. E., Linskey, A. R., Falbel, T. G., and Sharkey, T. D.: Development of the capacity for isoprene emission in kudzu, Plant Cell Environ., 28, 898-905, 2005. 